\section{Aspects of Large-Enrollment Online College Science Courses That Exacerbate and Alleviate Student Anxiety}

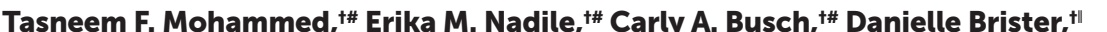
Sara E. Brownell, ${ }^{*}$ Chade T. Claiborne, ${ }^{\dagger "}$ Baylee A. Edwards, ${ }^{+\|}$Joseph Gazing Wolf, ${ }^{\dagger \|}$ Curtis Lunt, " Missy Tran, ${ }^{+\|}$Cindy Vargas, ${ }^{+\|}$Kobe M. Walker, ${ }^{+\|}$Tamiru D. Warkina, Madison L. Witt, ${ }^{\| 1}$ Yi Zheng, $\$$ and Katelyn M. Cooper**

${ }^{\dagger}$ Biology Education Research Course, School of Life Sciences, "Research for Inclusive STEM Education Center, and \$Mary Lou Fulton Teachers College, Arizona State University, Tempe, AZ 85281

\begin{abstract}
Anxiety is the top mental health concern for undergraduates. While researchers have identified ways that in-person science courses can affect anxiety, little is known about how online science courses affect anxiety. In this study, 2111 undergraduates at a large research-intensive institution completed survey questions about their anxiety in large-enrollment online science courses. Specifically, we assessed students' anxiety in the context of online science courses and asked what aspects of online science courses increase and decrease their anxiety. Students also identified what instructors can do to lessen anxiety in online classrooms. We used open coding and logistic regression to analyze student responses. More than $\mathbf{5 0 \%}$ of students reported at least moderate anxiety in the context of online college science courses. Students commonly reported that the potential for personal technology issues $(69.8 \%)$ and proctored exams $(68.0 \%)$ increased their anxiety, while being able to access content at a later time $(79.0 \%)$ and attending class from where they want $(74.2 \%)$ decreased their anxiety. The most common ways that students suggested that instructors could decrease student anxiety is to increase test-taking flexibility (25.0\%) and be understanding (23.1\%). This study provides insight into how instructors can create more inclusive online learning environments for students with anxiety.
\end{abstract}

\section{INTRODUCTION}

Anxiety, defined as an unpleasant emotional state characterized by subjective feelings of tension, apprehension, and worry (Spielberger, 2013), is the top reported mental health concern for undergraduates (Center for Collegiate Mental Health, 2021). The rate of undergraduate anxiety continues to rise (American College Health Association, 2019; Center for Collegiate Mental Health, 2021), and improving student mental health is of interest to colleges and universities (National Council on Disability, 2017; Hsu and Goldsmith, 2021). While low levels of anxiety have been shown to be motivating for students, high anxiety levels are reported to be exclusively detrimental (Deshpande and Kawane, 1982; Teigen, 1994). Individuals who experience anxiety can experience symptoms such as feelings of nervousness or tiredness, sweating and trembling, and trouble concentrating, which can lead to insomnia, social isolation, or issues performing in school (Mayo Clinic, 2021).

High levels of student anxiety have been shown to negatively affect student motivation and performance in college (McKeachie, 1951; Culler and Holahan, 1980; Fletcher and Carter, 2010; Vitasari et al., 2010; England et al., 2017, 2019; Hood et al., 2021). Student anxiety may be particularly detrimental in science courses owing to the rigor and difficulty of the material (Udo et al., 2004; Mallow, 2006) and the competitive, chilly and sometimes hostile environments (Seymour and Hewitt, 1997;
Rebecca Price, Monitoring Editor Submitted May 24, 2021; Revised Aug 27, 2021; Accepted Oct 1, 2021

CBE Life Sci Educ December 1, 2021 20:ar69 DOI:10.1187/cbe.21-05-0132

\#These authors contributed equally to this work and should be regarded as co-first authors. 'These authors contributed equally to this work. *Address correspondence to: Katelyn M. Cooper (katelyn.cooper@asu.edu).

(c) 2021 T. F. Mohammed, E. M. Nadile, C. A. Busch, et al. CBE-Life Sciences Education () 2021 The American Society for Cell Biology. This article is distributed by The American Society for Cell Biology under license from the author(s). It is available to the public under an Attribution-Noncommercial-Share Alike 4.0 International Creative Commons License (https://creativecommons .org/licenses/by-nc-sa/4.0).

"ASCB®" and "The American Society for Cell Biology $\circledR^{\prime \prime}$ are registered trademarks of The American Society for Cell Biology. 
Brainard and Carlin, 1998; Wyer et al., 2001). Studies have shown that students who report experiencing anxiety in college science courses perceive difficulty thinking through science problems and articulating their thoughts about science (Cooper et al., 2018a; Cooper and Brownell, 2020; Downing et al., 2020). Further, anxiety in college science courses has been negatively correlated with both students' performance (England et al., 2017, 2019; Hood et al., 2021) and plans to persist in biology degree programs (England et al., 2019).

Recent research has aimed to identify specific aspects of college science courses that affect student anxiety in an effort to identify potential targets for interventions that could make classrooms more inclusive for students. For example, studies have examined student anxiety as it relates to students asking and answering questions in large-enrollment courses (Nadile et al., 2021), as well as how active learning, defined as having students engage in their learning through activities and discussion in class (Freeman et al., 2014), affects student anxiety at research-intensive (R1) institutions (England et al., 2017; Cooper et al., 2018a; Adkins-Jablonsky et al., 2021) and community colleges (Downing et al., 2020; Hood et al., 2021). Collectively, these studies have identified that active-learning courses have the potential to increase students' anxiety because they often increase social interactions among students and between students and instructors. Particularly, fear of negative evaluation, or a student's sense of dread associated with being unfavorably evaluated while participating in a social situation (Watson and Friend, 1969; Weeks et al., 2005), is the primary factor underlying many students' anxiety in college science courses (Cooper et al., 2018a; Cooper and Brownell, 2020; Downing et al., 2020). Importantly, a limitation of the extant research examining the relationship between student anxiety and college science courses is that most studies have focused exclusively on the experiences of students taking in-person courses.

As online learning opportunities increase across higher education institutions, there is a greater need for research examining the relationship between student anxiety and online learning. In the past two decades, academic institutions and students have made great shifts toward online learning experiences and are capitalizing on the flexibility and accessibility that online courses offer (Allen and Seaman, 2013). The proportion of undergraduate students taking online courses quadrupled in the period from 2000 to 2012 (Protopsaltis and Baum, 2019); as of 2019, more than 400 universities in the United States offered solely online bachelor's degrees, including degrees in the sciences (McCarthy, 2019). Additionally, the COVID-19 pandemic accelerated the transition to online learning for higher education institutions in March of 2020, as many institutions opted to transition their in-person courses online ("Tracking the Coronavirus at U.S. Colleges and Universities," 2020). As of Fall 2020, 75\% of American institutions continued to deliver courses either completely or partially online ("Here's Our List of Colleges' Reopening Models," 2020). Given the magnitude of students who are currently engaging in online courses and the likelihood of online courses becoming common among institutions of higher education, identifying factors that exacerbate student anxiety online and mitigating anxiety to maximize student learning are of chief concern.
Studies of online courses before the pandemic provide some insight into what factors might affect student anxiety, although we know of no studies specifically targeting online college science courses. For example, a study of students in communication and information technologies found that $32 \%$ of students experienced an increase in anxiety when asked to collaborate with other students online because of the fear of being judged and having to rely on others (Hilliard et al., 2020). However, another study of students enrolled in a variety of online courses found that, on average, interactions in the course such as student-student and student-instructor interactions decreased anxiety in the virtual learning environment (Idemudia and Negash, 2012). In a study of students enrolled in online courses across multiple disciplines, researchers found that students' anxiety decreased as their prior experience in online courses and sense of preparedness increased. Finally, students in an online graduate program reported increased anxiety at the beginning of courses, particularly when the course content was unavailable before the beginning of class and when the schedule, including due dates and exam dates, was not posted (Conrad, 2002). Additionally, how instructors choose to teach has been shown to affect student anxiety in in-person courses and likely affects student anxiety in online courses as well. For example, instructors who make an effort to reassign students to the same online small groups may help students establish relationships with each other, decreasing their anxiety (Cooper et al., 2018a; Downing et al., 2020). Additionally, giving students appropriate time to think through science problems and even share their thoughts within a small group may decrease students' anxiety, but randomly calling on students to share their responses in front of the whole class would likely increase their anxiety (Downing et al., 2020; Cooper et al., 2021). While there are no prior studies directly examining student anxiety in online science courses, this previous work collectively provides some insights into what aspects of online courses may affect student anxiety in the context of college science.

Addressing anxiety in online science courses may disproportionately benefit students in certain demographic groups who are underrepresented and/or underserved in the sciences. For example, studies have shown individuals in particular demographic groups are more likely to report anxiety than their counterparts. Demographic groups who commonly report higher anxiety include women compared with men (Bayram and Bilgel, 2008; Bryant et al., 2013; Abdous, 2019; England et al., 2019; Misra and McKean, 2000), persons excluded because of their ethnicity or race (PEERs) compared with white students (Eckberg, 2015; England et al., 2019; Soria and Horgos, 2021), students with disabilities compared with students without disabilities (Hoy et al., 1997; Coduti et al., 2016), LGBTQ+ students compared with non-LGBTQ+ students (Oswalt and Wyatt, 2011; Grant et al., 2014), first-generation college students compared with continuing-generation students (Gaudier-Diaz et al., 2019), students with depression compared with those without depression (Eisenberg et al., 2007; Mahmoud et al., 2012), and students with financially unstable homes compared with those with financially stable homes (Eisenberg et al., 2007). A student's year in the undergraduate program may also affect anxiety levels; one study found that upperclassmen are more anxious than lowerclassmen (Beiter et al., 2015), but others have found that students in their first or second year have 
higher anxiety than their peers (Rawson et al., 1994; Bayram and Bilgel, 2008; England et al., 2019). These data suggest that student demographics may be important predictors of student anxiety, but it is unknown whether students from different demographic groups experience differing levels of anxiety in the specific context of online science courses.

In this study, we aimed to examine the anxiety of students enrolled in an in-person degree program who were taking science courses online because of the COVID-19 pandemic. Our research questions are as follows:

1. To what extent do undergraduates experience anxiety in the context of large-enrollment online college science courses, and do student demographics predict differences in anxiety levels?

2. To what extent and why do students traditionally enrolled in an in-person degree program experience different levels of anxiety in large-enrollment online science courses compared with in-person college science courses? Do demographics predict whether students are more likely to experience higher anxiety online or in person?

3. What factors increase students' anxiety in large-enrollment online college science courses? Do student demographics predict what increases students' anxiety?

4. What factors decrease students' anxiety in large-enrollment online college science courses? Do student demographics predict what decreases students' anxiety?

5. In students' opinions, what can instructors do to decrease student anxiety in large-enrollment online college science courses?

\section{METHODS}

The study was done with an approved Institutional Review Board protocol no. 13434 from Arizona State University.

This research project was conducted as part of a biology education course-based research experience, or CRE (also commonly known as a course-based undergraduate research experience or CURE; Auchincloss et al., 2014), in which 13 students along with the instructor conducted a biology education research project in the context of a course with the intent to publish their findings (Cooper and Brownell, 2018). Both life sciences undergraduate and graduate students were enrolled in the CRE, which was taught entirely online by K.M.C. during the Spring 2021 semester. The course was backward designed to develop students' scientific thinking, writing, information literacy, question formulation, study design, data analysis, interpretation, and evaluation skills (Cooper et al., 2017b; Clemmons et al., 2019; Turner et al., 2021). Together with the instructor, the students were responsible for the development of the research questions and survey tool, collecting and analyzing the data, and writing the manuscript. Henceforth, the students in the CRE are referred to as "CRE researchers" to distinguish them from undergraduates who served as participants in our study.

\section{Study Context}

For this study, we aimed to survey undergraduates who were enrolled in an in-person degree program who were completing large-enrollment science courses online due to the COVID-19 pandemic. As such, we conducted our study at a large R1 institution in the U.S. Southwest where the majority of large-enroll- ment science courses for the in-person program were offered exclusively online in Summer 2020, Fall 2020, and Spring 2021. We chose to focus the study on large-enrollment courses because class size may affect student anxiety (Cooper et al., 2018a; England et al., 2019; Downing et al., 2020) and because these courses were most likely to be offered exclusively online. The COVID-19 pandemic provided a unique situation to answer our research questions; compared with prior semesters at the institution where this research was conducted, thousands more students were engaging in online science coursework and could provide insight into aspects of online courses that affect anxiety. However, we acknowledge that this study was conducted during the COVID-19 pandemic, a time of racial unrest and racially driven hate crimes, the Black Lives Matter movement, and months after U.S. political tensions resulted in a riot at the U.S. Capitol Building, all of which may have affected student anxiety (Chou et al., 2012; Kecojevic et al., 2020; Kibbey et al., 2020; Ni et al., 2020; Lee et al., 2021). As such, we intentionally directed students to think about their anxiety in the specific context of their online science courses as opposed to their anxiety more generally.

\section{Survey Development}

To answer our research questions, we developed a survey that was distributed via Qualtrics. Thirteen CRE researchers reviewed the survey and recommended modifications using criteria to assess all questions (e.g., Is this question grammatically correct? Is the meaning of this question clear?; Bowden et al., 2002). After revising the survey, five CRE researchers conducted think-aloud interviews with undergraduates who were taking online science courses to establish cognitive validity of the survey by checking to see whether students understood what each question was asking (Trenor et al., 2011). The survey was iteratively revised based on each student's feedback. The survey was then circulated among three biology education researchers who were not directly involved with this project, one of whom is an expert on anxiety in the context of biology courses. The survey was revised again based on their recommendations. Thirteen CRE researchers reviewed the survey a final time before it was distributed to students. A copy of the survey questions that were analyzed for this study is provided in the Supplemental Material.

\section{Survey Distribution}

We emailed all instructors teaching life sciences courses at the R1 institution ( $n=127$ ) in March of 2021 and asked if they would be willing to distribute our survey about students' mental health to students in their online science courses. Of the instructors contacted, 38 (29.9\%) agreed to send the survey out to their students in their course(s) in exchange for extra credit or in exchange for the student to enter a raffle to win one of two $\$ 100$ gift cards. Multiple instructors distributed the survey in more than one of their courses. Based on course enrollment numbers at the time, we estimate that the survey was sent to a total of $\sim 4450$ life sciences students. We chose to recruit from the life sciences department because it is the largest in the natural sciences and because students in these courses were likely to be enrolled in multiple online science courses at once. In total, 2175 students $(48.8 \%$ of students who were sent the survey) recruited from 55 unique life sciences courses completed 
the survey. The number of students recruited from specific course types (e.g., neurobiology, microbiology) are reported in the Supplemental Material.

\section{Survey Questions and Analysis}

Screening Questions and Demographics. The first question on the survey asked students how many large-enrollment online college science courses they had enrolled in. We defined large-enrollment as a course of 100 or more students (Nadile et al., 2021) and science courses to be any biology, chemistry, geosciences, or physics courses. Only students who had completed at least one large-enrollment online college science course were included in the analyses to answer our research questions. Additionally, we asked students how many in-person large-enrollment college science courses they had enrolled in. Only students who had enrolled in at least one large-enrollment online and at least one large-enrollment in-person course were included in the analyses comparing student experiences online and in person. At the end of the survey, students were asked a series of demographic questions. A copy of the survey questions analyzed in this study can be found in the Supplemental Material. The remaining survey questions are described in the following sections in line with the respective research questions they were analyzed to answer.

$R Q$ 1: To What Extent Do Undergraduates Experience Anxiety in the Context of Large-Enrollment Online College Science Courses, and Do Student Demographics Predict Differences in Anxiety Levels? To investigate the extent to which undergraduates experience anxiety in the context of online college science courses, we asked students to indicate their average level of anxiety in the context of large-enrollment online college science courses on a Likert scale: 1) little to no anxiety, 2) mild anxiety, 3) moderate anxiety, or 4) severe anxiety. We calculated the percent of students who selected each anxiety level. Then, we used multinomial logistic regression to determine to what extent students' demographics predict differences in anxiety levels. Multinomial logistic regression is an approach for modeling the relationship between more than two categorically distributed dependent variables, in this case whether a student reported experiencing 1) little to no or mild anxiety, 2) moderate anxiety, or 3) severe anxiety in the context of large-enrollment online college science courses. We decided to combine little to no anxiety and mild anxiety into one category to limit our dependent variable to a total of three distinct options, because we were most interested in whether there were differences in demographics among students with lower anxiety (none, little, or mild), moderate anxiety, and severe anxiety. We chose which predictors to include in our model based on prior literature suggesting that particular demographics may affect student anxiety. Our predictors included gender (man/woman), race/ethnicity (white, Asian, Black, Latinx), college generation status (first generation/continuing generation), LGBTQ+ status (yes/no), financial stability while taking online science courses (financially stable, not financially stable, sometimes financially stable), science, technology, engineering, and math (STEM) major (yes/no), grade point average (GPA; self-reported using a four-point scale), history of depression (yes/no), year in school (lowerclassmen/upperclassmen), and experience in online science courses (less experienced/more experienced). Model: severity of anxiety (low/moderate/severe) $\sim$ gender + race/ethnicity + college generation status + LGBTQ + status + financial stability + STEM major + GPA + depression + year in school + experience online. We recognize that not all individuals identify as gender binary (man or woman; Cooper et al., 2020a), but there were too few students who identified as a gender other than man or woman to create a third category for analyses. Additionally, we excluded students who identified as American Indian or Alaska Native, Pacific Islander, or as a race not listed on the survey from the analyses owing to low sample sizes. We combined first- and second-year undergraduate students into a single category, "lowerclassmen," and students who were in their third year or later of their undergraduate careers into "upperclassmen." We considered students who reported taking one to three large-enrollment online college science courses as having "less experience online" and students who had taken four or more large-enrollment online college science courses as having "more experience online." We also grouped students into science, technology, engineering, and math (STEM) majors and non-STEM majors, because we perceived that students with STEM majors may have different experiences in online science courses than students in non-STEM majors (Cotner et al., 2017; Michaluk et al., 2018).

$R Q$ 2: To What Extent and Why Do Students Traditionally Enrolled in an In-Person Degree Program Experience Different Levels of Anxiety in Large-Enrollment Online Science Courses Compared with In-Person College Science Courses? Do Demographics Predict Whether Students Are More Likely to Experience Higher Anxiety Online or In Person? We asked all students who had completed at least one large-enrollment online and one large-enrollment in-person college science course to compare their average level of anxiety between the two modalities; students could respond that, on average, their anxiety was higher, lower, or the same in online courses compared with in-person courses. Afterward, students were provided an open-ended question asking them to explain why they perceived their anxiety to be higher, lower, or the same in online courses compared with in-person courses.

We calculated the percent of students that reported higher, lower, or the same amount of anxiety in online courses compared with in-person courses. We used open-coding methods (Saldaña, 2015) to identify why students perceived their anxiety to be higher, lower, or the same in online courses. Two CRE researchers (T.F.M. and T.D.W.) reviewed a randomly selected set of 40 student responses explaining why their anxiety was higher in large-enrollment online college science courses compared with in-person courses and took detailed analytic notes to identify emerging themes (Birks and Mills, 2015). Then, the researchers convened, compared their notes, and developed a preliminary coding rubric. Together, they read through an additional 100 student responses to refine the rubric. The team of researchers then tested their coding rubric by reading through an additional 40 responses together and used constant comparison methods to verify that quotes within a category were similar to one another and not too different to warrant the creation of a new theme (Glesne and Peshkin, 1992). Once the final rubric was established, the two CRE researchers used the rubric to code all student responses to consensus (Stemler, 2004). Each theme in the rubric is mutually exclusive; that is, an 
excerpt of text could only be coded as one theme. However, students' full responses often included multiple themes.

These methods were repeated to identify common themes as to why students reported lower anxiety in online courses compared with in-person courses (data analyzed by CRE researchers D.B. and K.M.W.) and why students reported experiencing the same amount of anxiety in both environments (data analyzed by CRE researchers E.M.N. and C.T.C.). The final coding rubrics for each question are included in the Supplemental Material.

We used multinomial logistic regression to assess whether student demographics predicted whether a student reported that, compared with in-person courses they experienced 1) higher anxiety in online courses, 2) the same amount of anxiety in online courses, or 3) lower anxiety in online courses. Model: anxiety online compared with in person (higher/same/ lower) $\sim$ gender + race/ethnicity + college generation status + LGBTQ+ status + financial stability + STEM major + GPA + depression + year in school + experience online.

$R Q 3$ and RQ4: What Factors Increase/Decrease Students' Anxiety in Large-Enrollment College Science Courses? Do Student Demographics Predict What Increases/Decreases Students' Anxiety? Students were given two open-ended questions and asked to list as many aspects of large-enrollment online science courses they could think of that increased and decreased their anxiety. After students completed the openended questions, they were presented with two closed-ended questions asking them to 1) select from a list of 16 aspects of online college science courses that increased their anxiety (e.g., the potential for personal technology issues, difficulty getting help from other students in class) and 2) to select from a list of 18 aspects of online college science courses that decreased their anxiety (e.g., being able to access content at a later time, not having to be on camera). For each list, students were asked to select as many aspects as applied to them. Aspects listed in the closed-ended questions were developed by reviewing the literature for aspects of online courses that may affect student anxiety (e.g., Conrad, 2002; Stiller and Köster, 2016) and by identifying common experiences from the undergraduate student researchers in the CRE who were all originally enrolled in an in-person degree program but taking science courses online (see the Positionality Statement to learn more about the CRE student researchers). We chose to identify the factors that affect student anxiety using both open- and closed-ended questions, because the open-ended questions do not confine what students can report and the closed-ended questions allow students to consider their experiences from a more holistic perspective. Additionally, the closed-ended questions could be used as outcome variables in models examining potential demographic differences. We compared students' open-ended responses with the closed-ended responses and found that closed-ended responses were generally reflective of students' open-ended responses. The specific analyses are described below.

Open-coding methods were used to identify themes that increased students' feelings of anxiety from open-ended responses (Saldaña, 2015). Two CRE researchers (B.A.E. and M.T.) independently reviewed a randomly selected set of 40 student responses, took note of any repeated emergent themes, and developed a preliminary coding rubric (Birks and Mills,
2015). Together they read through an additional 100 student responses to refine the rubric using constant comparison methods (Glesne and Peshkin, 1992) and tested its efficacy on another 40 responses. Once the final rubric was established, the pair of researchers used the rubric to code a subset of 317 responses (15\% of total responses) to consensus (Stemler, 2004). See the Supplemental Material for a copy of the coding rubric. Coding approximately $20 \%$ of qualitative data in large sample sets (in this case, 140 students to test the efficacy of the rubric and the additional 317 responses total more than $20 \%$ of all responses) is considered enough to be representative of the entire data set (Syed and Nelson, 2015).

To determine the relationship between the predetermined closed-ended responses and students' open-ended response, the two CRE researchers calculated the percent of students who selected each closed-ended response and compared them with the themes that emerged from students' responses to the openended questions. Because the open-ended responses generally reflect the closed-ended responses, we only report the analyses of the closed-ended responses within the article. The categories that emerged from the open-ended responses and the percent of students who reported each category are reported in the Supplemental Material.

We used binary logistic regression, an approach for modeling the relationship between two or more independent variables, or predictors, and a dependent variable that is dichotomous in nature, to test whether there were demographic differences among students who selected each factor of online science courses that increased their anxiety (model: selected factor (yes/no) $\sim$ gender + race/ethnicity + college generation status + LGBTQ+ status + financial stability + STEM major + GPA + depression + year in school + experience online + anxiety).

Another pair of CRE researchers (J.G.W. and C.L.) repeated the process described previously with factors that decreased student anxiety. The final coding rubric for the open-ended question about what decreases students' anxiety and the percent of students who reported each theme is included in the Supplemental Material. The CRE researchers determined that the open-ended responses generally reflected the closed-ended responses. As such, we only report the analyses of the closedended responses within the article.

RQ5: In Students' Opinions, What Can Instructors Do to Decrease Student Anxiety in Large-Enrollment Online College Science Courses? To identify specific ways to help reduce student anxiety in online classrooms, we used an open-ended question to give students the opportunity to suggest what they believe instructors of large-enrollment online science courses could do to decrease student anxiety. Starting with a randomly selected set of 40 student responses, two CRE researchers (C.V. and M.L.W.) individually reviewed and wrote down detailed analytic notes on what they perceived as common themes emerging from student responses (Birks and Mills, 2015). Then, the two CRE researchers convened and compared their notes describing the themes they had identified to develop a preliminary coding rubric. Together, they then read through an additional 100 student responses to locate and address any discrepancies with the initial coding rubric. The researchers used constant comparison methods to verify that students' quotes were similar enough to fall within the same category and did not 
differ enough to warrant a new category (Glesne and Peshkin, 1992). The team of researchers then tested their coding rubric by reading through an additional 40 responses together. Students' full responses to the question often included multiple themes, but each phrase within a response was only coded once. Once the final rubric was established, the two researchers used the rubric to code a representative sample of the data $(30 \%, n=$ 634 student responses) to consensus (Stemler, 2004). The researchers reached saturation after coding approximately 150 student responses, indicating that no additional new themes were emerging from the data set (Morse et al., 2002).

\section{Reporting of Results}

We recognize that the significance of a result from any statistical test is continuous rather than dichotomous based on the specific $p$ value (Wasserstein et al., 2019). However, we report select results by the criterion of $p \leq 0.05$ throughout the Results section for simplicity. We acknowledge that test results with $p$ values greater than 0.05 can still be scientifically meaningful, and therefore we report out all results of statistical tests in the Supplemental Material for the reader's further interpretation. Additionally, we describe our results using language such as "women had $1.2 \times$ higher odds than men of selecting a particular factor." The number, "1.2" in this case, is the natural exponential of the estimated coefficient for the explanatory variable, in this case "women" versus "men," in the logistic regression model to predict whether the student will select a particular factor. This number is also called the "odds ratio," which is a standardized effect size statistic in logistic regression (Deeks, 1998; Agresti and Franklin, 2012). For all themes that emerged from student open-ended responses, we decided to include those reported by at least $10 \%$ of students. However, for student recommendations about how instructors could decrease anxiety, we highlight themes reported by at least $5 \%$ of students, as there were a substantial number of themes between $5 \%$ and $10 \%$ that we felt would be of interest to the reader.

\section{Positionality Statement}

The research team collectively identify as men or women and represent multiple races and ethnicities including Asian, American Indian, Black, Creole, Latinx, and white. About half of the researchers are the first in their families to attend college. Some researchers identify as struggling with anxiety or an anxiety disorder and some do not. At the time the research was conducted, nine CRE researchers were undergraduates and four were graduate students. We used our diverse identities and experiences to try and counteract implicit biases in the way we collected, analyzed, and evaluated the data for this research (Intemann, 2009).

\section{RESULTS}

\section{Participants}

A total of 2175 students completed the survey, and $97.1 \%$ of those students ( $n=2111$ ) had completed at least one large-enrollment online college science course. Eighty eight percent of students reported taking at least one synchronous online science course, and 55.3\% reported taking at least one asynchronous online science course. Students were primarily women (66.6\%), white $(48.1 \%)$, continuing-generation college students $(58.5 \%)$, and in their first or second year of college (58.6\%). Additionally, $40.6 \%$ of students reported that they did not consider themselves financially stable or only considered themselves financially stable sometimes while completing online college science courses. Nearly $17 \%$ of students identified as a member of the LGBTQ+ community, and $53.8 \%$ of students identified as having depression. Student demographics are summarized in Table 1.

\section{Finding 1. Students Most Commonly Reported Moderate Anxiety in the Context of Large-Enrollment Online Science Courses and Women, Students Who Are Financially Unstable, and Those with Depression Experience Higher Anxiety Than Their Counterparts}

Of the 2111 survey participants, 19.7\% reported experiencing little to no anxiety, $29.2 \%$ reported mild anxiety, $37.2 \%$ reported moderate anxiety, and $13.9 \%$ reported experiencing severe anxiety in their large-enrollment online college science courses (Figure 1).

Comparing students who experienced no to mild anxiety with those who experienced moderate and severe anxiety, we identified significant demographic differences between groups. Women, students who were financially unstable, and students with depression were more likely than men, students who were financially stable, and students without depression to report both moderate and severe anxiety. Additionally, students with more experience in online courses were more likely to report moderate anxiety compared with students with less experience, and STEM majors were more likely to report severe anxiety compared with non-STEM majors. The results of the multinomial regression are summarized in Figure 2 and reported in full in the Supplemental Material.

\section{Finding 2. Students Were More Likely to Report That They Have Higher Anxiety in Their Large-Enrollment Online College Science Courses Compared with Large-Enroll- ment In-Person College Science Courses}

Of the 893 students who reported having enrolled in at least one large-enrollment online science course and one large-enrollment in-person science course, $39.9 \%$ of students reported that they have higher anxiety in online science courses compared with in-person science courses. Conversely, 27.0\% of students reported that they have lower anxiety in online science courses compared with in-person science courses, and $33.1 \%$ reported experiencing the same amount of anxiety in each modality. We identified a number of significant demographic differences in students' anxiety levels in online versus in-person science courses. Lowerclassmen had 1.7 times higher odds than upperclassmen of reporting higher anxiety online (compared with lower anxiety online), and students with depression had 2.0 times higher odds than students without depression of reporting higher anxiety online (compared with reporting the same anxiety online and in person). No other demographic differences predicted whether students reported differing levels of anxiety in large-enrollment online science courses compared with in-person science courses. Full results of the logistic regression assessing demographic differences are reported in the Supplemental Material.

Of the students who reported experiencing higher anxiety in online courses, $99.4 \%$ of students responded to the open-ended question asking them to explain why. Of those respondents, students most commonly reported that they perceived learning 


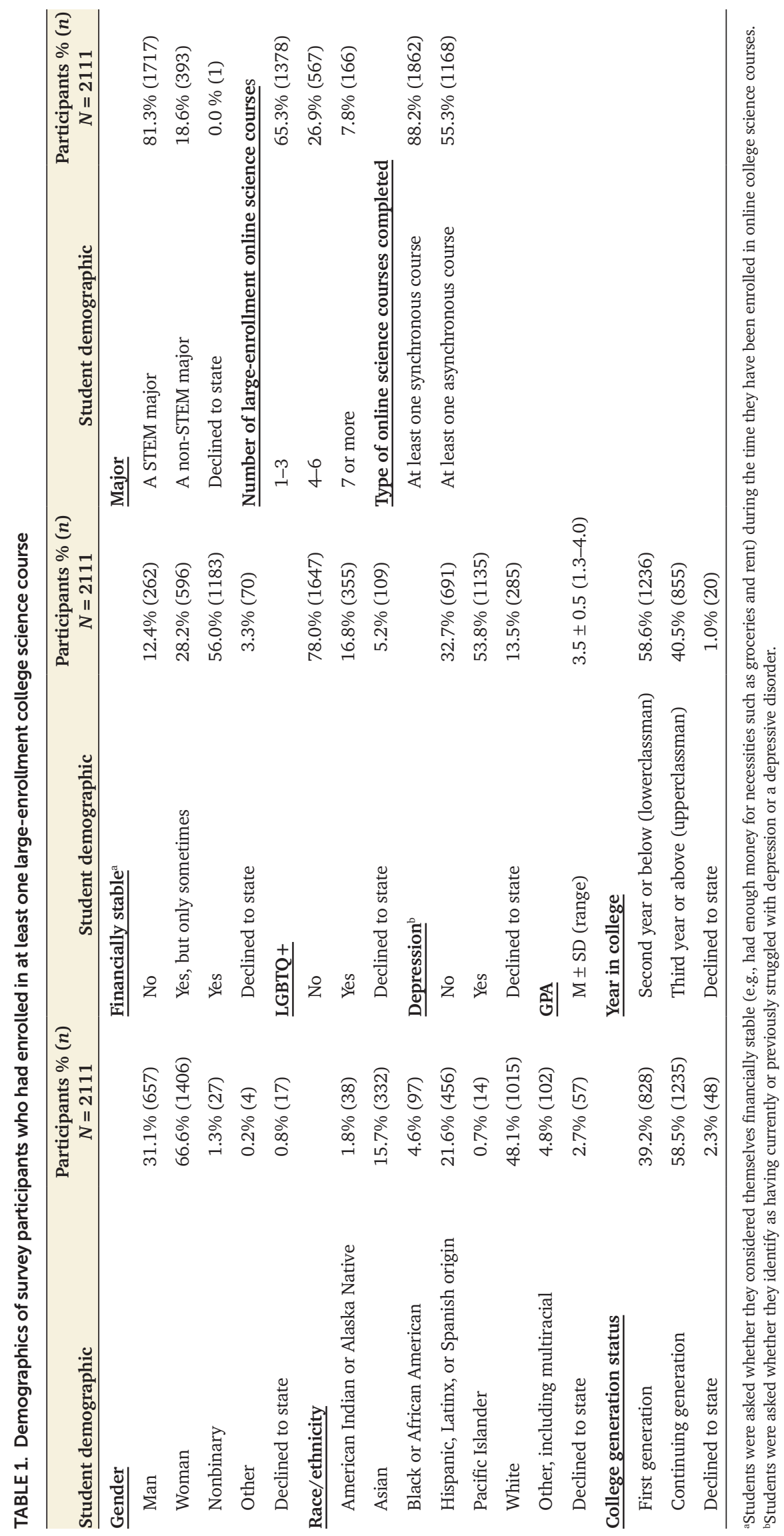




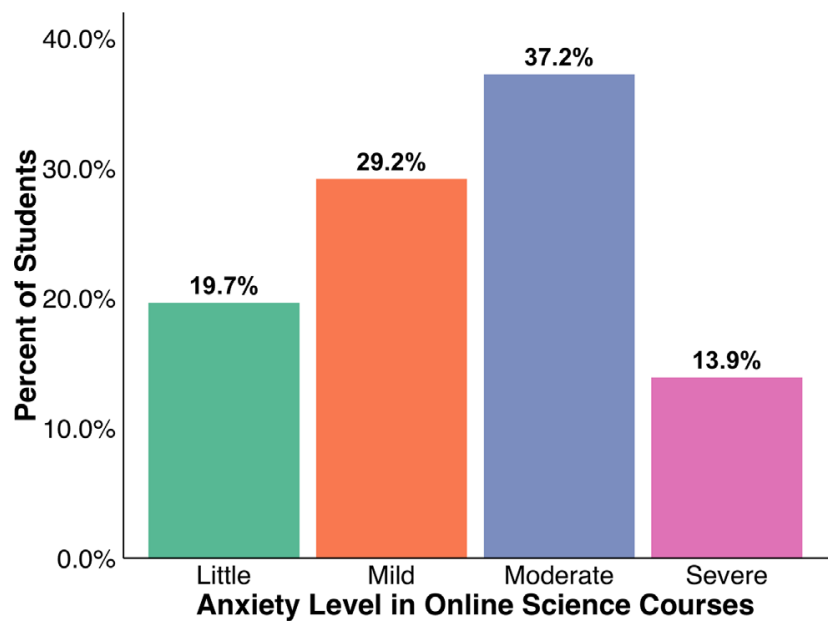

FIGURE 1. Students' average level of anxiety in online college science courses $(n=2111)$.

to be more difficult online (55.7\%), often describing that it was hard for them to learn independently, stay engaged, or teach themselves online. Students also described that their anxiety is higher online, because they find it more difficult to be organized, self-paced, or keep track of due dates online compared with in person (21.2\%). Finally, students commonly reported that making connections with students is more difficult online (21.2\%).
The most common reasons reported by at least $10 \%$ of students as to why their anxiety is higher in online science courses compared with in-person science courses are reported with example student responses in Table 2.

Of the students who reported experiencing lower anxiety in large-enrollment online college science courses, $99.2 \%$ responded to the question asking them why this was the case. Of the respondents, students most commonly mentioned that they had lower anxiety online compared with in person because they were able to learn in a comfortable or familiar environment (39.7\%), because they did not have to stress about physically getting to class (15.9\%), and because they perceive the material is easier to follow or more readily available online compared with in person (15.9\%). The most common reasons reported by at least $10 \%$ of students as to why students experience less anxiety in online science courses and example student responses are reported in Table 3.

Of the students who reported experiencing the same amount of anxiety in online courses compared with in-person courses, $98.3 \%$ of students provided a response to the question asking them why they perceived their anxiety levels to be the same in both environments. More than half of students reported that they experienced the same amount of anxiety in online courses compared with in-person courses because the factors that affect their anxiety are present in both online and in-person courses (52.1\%). For example, $20.3 \%$ of students said that anxiety is the same because the workload and assignments are similar in both environments, and $10.7 \%$ of students said that they approach online and in-person courses or exams in the same way, resulting in the same amount of anxiety (common subthemes are reported in the Supplemental Material). Students also reported that anxiety can be the same in both online and in-person courses because aspects of a course that differ online and in person affect their anxiety the same amount (23.4\%); for example, some students report that large-enrollment online and in-person courses have different stressors that affect their anxiety levels similarly. Finally, students reported that anxiety can be the same in both online and in-person courses because of personal factors (19.7\%). For example, students reported that they are generally nervous or anxious or generally have low anxiety. The three primary reasons why students reported the same levels of anxiety are reported in Table 4 with example student quotes.

\section{Finding 3: Students Most Commonly Reported That Technology Issues, Online Exams, and Difficulty Getting to Know Other Students Increased Their Anxiety in Large-Enrollment Online College Science Courses}

The aspects that students most frequently selected as increasing their anxiety were the potential for technology issues 
TABLE 2. The most common reasons why students report higher anxiety in large-enrollment college science courses compared with in-person courses ${ }^{\mathrm{a}}$

\begin{tabular}{|c|c|c|c|c|}
\hline Category & Category description & $\begin{array}{c}\%(n) \\
N=354\end{array}$ & Example student response & Example student response \\
\hline $\begin{array}{l}\text { Learning is more } \\
\text { difficult online. }\end{array}$ & $\begin{array}{l}\text { Student describes their anxiety } \\
\text { is higher in online courses } \\
\text { compared with in person } \\
\text { because it is more difficult } \\
\text { to pay attention and stay } \\
\text { engaged or focused. }\end{array}$ & $\begin{array}{l}55.7 \% \\
(197)\end{array}$ & $\begin{array}{l}\text { Student } 181 \text { : "I just feel like I have } \\
\text { to work } 100 \times \text { harder to } \\
\text { understand the material in an } \\
\text { online course. A lot more goes } \\
\text { into teaching myself the material } \\
\text { because I don't get to sit in a } \\
\text { lecture hall and absorb } \\
\text { information by being in a } \\
\text { physical academic setting." }\end{array}$ & $\begin{array}{l}\text { Student 275: "It's extremely difficult } \\
\text { to stay focused when there is just } \\
\text { less engagement overall. I feel like } \\
\text { a failure because I'm just not } \\
\text { absorbing knowledge." }\end{array}$ \\
\hline $\begin{array}{l}\text { It is more difficult to } \\
\text { stay organized } \\
\text { and keep up with } \\
\text { online course- } \\
\text { work. }\end{array}$ & $\begin{array}{l}\text { Student describes their anxiety } \\
\text { is higher in online courses } \\
\text { compared with in person } \\
\text { because it is more difficult } \\
\text { to stay on top of or ahead } \\
\text { of assignments and easier } \\
\text { to fall behind or procrasti- } \\
\text { nate. }\end{array}$ & $\begin{array}{c}21.2 \% \\
(75)\end{array}$ & $\begin{array}{l}\text { Student 951: "It is harder for me to } \\
\text { stay on track and keep myself } \\
\text { accountable when all of my } \\
\text { learning is happening in an } \\
\text { environment that my brain } \\
\text { associates with relaxation and } \\
\text { play (childhood bedroom)." }\end{array}$ & $\begin{array}{l}\text { Student 97: "I'm more uncertain } \\
\text { when due dates are [in my online } \\
\text { courses]. There's this feeling of } \\
\text { constantly needing to check [the } \\
\text { online course platform] and my } \\
\text { email to make sure I'm not } \\
\text { missing anything." }\end{array}$ \\
\hline $\begin{array}{l}\text { Making connections } \\
\text { with students is } \\
\text { more difficult. }\end{array}$ & $\begin{array}{l}\text { Student describes their anxiety } \\
\text { is higher in online courses } \\
\text { compared with in person } \\
\text { because it is harder to } \\
\text { connect and interact with } \\
\text { students or form study } \\
\text { groups online. }\end{array}$ & $\begin{array}{l}21.2 \% \\
(75)\end{array}$ & $\begin{array}{l}\text { Student 964: "It comforts me to } \\
\text { know that there are many } \\
\text { students in my classes where we } \\
\text { can interact in person. Many } \\
\text { times, online, people are } \\
\text { nervous to unmute themselves } \\
\text { and there are no opportunities to } \\
\text { talk and meet classmates during } \\
\text { online lectures." }\end{array}$ & $\begin{array}{l}\text { Student 885: "I am unable to engage } \\
\text { with other people physically, } \\
\text { which I would typically [do] in a } \\
\text { classroom. That helps me share } \\
\text { my ideas and discuss certain } \\
\text { topics to [sic] my fellow } \\
\text { classmates." }\end{array}$ \\
\hline $\begin{array}{l}\text { Making connections } \\
\text { with instructors is } \\
\text { more difficult. }\end{array}$ & $\begin{array}{l}\text { Student describes their anxiety } \\
\text { is higher in online courses } \\
\text { compared with in person } \\
\text { because there are limited } \\
\text { opportunities to connect } \\
\text { with instructors online. }\end{array}$ & $\begin{array}{c}20.6 \% \\
(73)\end{array}$ & $\begin{array}{l}\text { Student 1191: "There's not an } \\
\text { actual connection with the } \\
\text { professors, it seems like they } \\
\text { care less about their students' } \\
\text { well-being because they usually } \\
\text { can't see us." }\end{array}$ & $\begin{array}{l}\text { Student 1203: "There are fewer } \\
\text { opportunities to interact with the } \\
\text { professors [...] about vital } \\
\text { information about the course } \\
\text { material." }\end{array}$ \\
\hline $\begin{array}{l}\text { There are distractions } \\
\text { when trying to } \\
\text { learn online. }\end{array}$ & $\begin{array}{l}\text { Student describes their anxiety } \\
\text { is higher in online courses } \\
\text { compared with in person } \\
\text { because there are more } \\
\text { distractions, such as those } \\
\text { at home or those caused by } \\
\text { other students. }\end{array}$ & $\begin{array}{c}15.3 \% \\
(54)\end{array}$ & $\begin{array}{l}\text { Student 1188: "I am always } \\
\text { distracted when I'm at home." }\end{array}$ & $\begin{array}{l}\text { Student 191: "Since I live at home } \\
\text { with two nieces, I get anxiety for } \\
\text { not being able to concentrate." }\end{array}$ \\
\hline $\begin{array}{l}\text { Taking exams is more } \\
\text { difficult online. }\end{array}$ & $\begin{array}{l}\text { Students describes their } \\
\text { anxiety is higher in online } \\
\text { courses compared with in } \\
\text { person because of } \\
\text { exam-related concerns, } \\
\text { such as proctoring, } \\
\text { scheduling, or the amount } \\
\text { of time the exam is open. }\end{array}$ & $\begin{array}{l}14.1 \% \\
(50)\end{array}$ & $\begin{array}{l}\text { Student 447: "Many of the online } \\
\text { college science courses have } \\
\text { rigorous proctoring systems that } \\
\text { involve the camera and } \\
\text { microphone being on whereas } \\
\text { with in-person classes, the } \\
\text { proctoring is less intense (for } \\
\text { example, the online proctoring } \\
\text { says you cannot look anywhere } \\
\text { other than the screen). Though I } \\
\text { understand the purpose of } \\
\text { proctored exams, it is very } \\
\text { overwhelming because I am so } \\
\text { afraid of being flagged for } \\
\text { academic dishonesty just for } \\
\text { looking down for a moment to } \\
\text { think." }\end{array}$ & $\begin{array}{l}\text { Student 651: "Proctored exams give } \\
\text { me so much anxiety because I'm } \\
\text { so terrified that if my family } \\
\text { members make noise I will be } \\
\text { flagged or if my eyes are } \\
\text { wandering because I am trying to } \\
\text { remember an answer I will be } \\
\text { flagged. I spend so much time } \\
\text { putting in the work and feel like } \\
\text { that would not be recognized due } \\
\text { to such high anxiety of being } \\
\text { watched behind a camera. It is so } \\
\text { frustrating and increases my stress } \\
\text { so much." }\end{array}$ \\
\hline
\end{tabular}


TABLE 2. Continued

\begin{tabular}{|c|c|c|c|c|}
\hline Category & Category description & $\begin{array}{c}\%(n) \\
N=354\end{array}$ & Example student response & Example student response \\
\hline $\begin{array}{l}\text { There are greater } \\
\text { workloads } \\
\text { and higher } \\
\text { expectations } \\
\text { online. }\end{array}$ & $\begin{array}{l}\text { Students describes their } \\
\text { anxiety is higher in online } \\
\text { courses compared with in } \\
\text { person because they } \\
\text { perceive there is an } \\
\text { increased workload, higher } \\
\text { expectations, or that online } \\
\text { courses are at a faster pace } \\
\text { compared with in-person } \\
\text { courses. }\end{array}$ & $\begin{array}{c}11.3 \% \\
(40)\end{array}$ & $\begin{array}{l}\text { Student 1086: "It feels like more } \\
\text { material is required from you } \\
\text { when the class is online because } \\
\text { the professors can give you } \\
\text { content that would ordinarily } \\
\text { take too long in an in-person } \\
\text { classroom. It feels like most } \\
\text { professors have been giving } \\
\text { more work now that classes are } \\
\text { online and we "have more time."” }\end{array}$ & $\begin{array}{l}\text { Student 408: "The deadlines and } \\
\text { workload for STEM classes online } \\
\text { is [sic] unrealistic. Increasing the } \\
\text { workload and deadlines and } \\
\text { expecting students to continu- } \\
\text { ously perform at an exceptional } \\
\text { level despite shortening the } \\
\text { amount of time to prepare and } \\
\text { increasing the amount of work is } \\
\text { highly unrealistic." }\end{array}$ \\
\hline
\end{tabular}

${ }^{a}$ Of the 356 students who reported having higher anxiety online compared with in person, 354 students answered the open-ended question about why their anxiety was higher in this environment. Themes reported by at least $10 \%$ of students are summarized. Additional themes reported by at least $5 \%$ of students are reported in the Supplemental Material.

TABLE 3. The most common reasons why students report lower anxiety in large-enrollment college science courses compared with in-person courses

\begin{tabular}{|c|c|c|c|c|}
\hline Category & Category description & $\begin{array}{c}\%(n) \\
N=239\end{array}$ & Example student response & Example student response \\
\hline $\begin{array}{l}\text { The student can learn in a } \\
\text { comfortable or familiar } \\
\text { environment. }\end{array}$ & $\begin{array}{l}\text { Student describes their anxiety } \\
\text { is lower in online courses } \\
\text { compared with in person } \\
\text { because they are in a } \\
\text { familiar and comfortable } \\
\text { environment. }\end{array}$ & $\begin{array}{c}39.7 \% \\
(95)\end{array}$ & $\begin{array}{l}\text { Student 214: "[My anxiety is lower } \\
\text { in online science courses } \\
\text { because] I am in my own space } \\
\text { where I am the most comfort- } \\
\text { able, so I am less anxious." }\end{array}$ & $\begin{array}{l}\text { Student 1595: "I have less } \\
\text { anxiety in online classes } \\
\text { because I am attending } \\
\text { them in the comfort of my } \\
\text { own home." }\end{array}$ \\
\hline $\begin{array}{l}\text { The student does not have } \\
\text { to physically get to } \\
\text { class. }\end{array}$ & $\begin{array}{l}\text { Student describes their anxiety } \\
\text { is lower in online courses } \\
\text { compared with in person } \\
\text { because time is not wasted } \\
\text { commuting to, getting to, or } \\
\text { walking to classes. }\end{array}$ & $\begin{array}{c}15.9 \% \\
(38)\end{array}$ & $\begin{array}{l}\text { Student 239: "[In my online science } \\
\text { courses], I don't have anxiety } \\
\text { about being late to class (as a } \\
\text { student-athlete it was } \\
\text { challenging to attend practices } \\
\text { and then have to rush over to } \\
\text { class on campus)." }\end{array}$ & $\begin{array}{l}\text { Student 495: "I have lower } \\
\text { anxiety because time } \\
\text { management and schedul- } \\
\text { ing are much easier } \\
\text { [online]. Instead of having } \\
\text { to walk to classes and be in } \\
\text { person, I can work on } \\
\text { homework in between } \\
\text { classes and take notes more } \\
\text { easily when classes are } \\
\text { online." }\end{array}$ \\
\hline $\begin{array}{l}\text { The material is easier to } \\
\text { follow or more readily } \\
\text { available online. }\end{array}$ & $\begin{array}{l}\text { Student describes their anxiety } \\
\text { is lower in online courses } \\
\text { compared with in person } \\
\text { because the material is } \\
\text { easier to follow or more } \\
\text { accessible through the } \\
\text { recording of lectures. }\end{array}$ & $\begin{array}{l}15.9 \% \\
(38)\end{array}$ & $\begin{array}{l}\text { Student } 120 \text { : "I am not excessively } \\
\text { worried about missing/not } \\
\text { catching what the professor says } \\
\text { during lecture, as all of the } \\
\text { videos are posted and I can } \\
\text { rewatch them at any time." }\end{array}$ & $\begin{array}{l}\text { Student 1264: "I can rewatch } \\
\text { recorded lecture videos and } \\
\text { pause them if I need to } \\
\text { finish writing something } \\
\text { else down." }\end{array}$ \\
\hline $\begin{array}{l}\text { There are fewer social } \\
\text { interactions online. }\end{array}$ & $\begin{array}{l}\text { Student describes their anxiety } \\
\text { is lower in online courses } \\
\text { compared with in person } \\
\text { because it requires fewer } \\
\text { personal interactions and } \\
\text { does not exacerbate social } \\
\text { anxiety. }\end{array}$ & $\begin{array}{c}14.2 \% \\
(34)\end{array}$ & $\begin{array}{l}\text { Student 282: "I have an anxiety } \\
\text { disorder and social situations } \\
\text { can tend to make me anxious. I } \\
\text { feel like there are less [social } \\
\text { situations] in an online class } \\
\text { than in person classes [which } \\
\text { lowers my anxiety in my online } \\
\text { science courses]." }\end{array}$ & $\begin{array}{l}\text { Student 1791: "I feel less } \\
\text { anxiety not being in person } \\
\text { because I don't have to be } \\
\text { face-to-face and actually } \\
\text { interact with students or } \\
\text { teachers." }\end{array}$ \\
\hline $\begin{array}{l}\text { The student can be } \\
\text { anonymous online. }\end{array}$ & $\begin{array}{l}\text { Student describes their anxiety } \\
\text { is lower in online courses } \\
\text { compared with in person } \\
\text { because you can be } \\
\text { anonymous or do not have } \\
\text { to show your face and can } \\
\text { choose not to be heard. }\end{array}$ & $\begin{array}{c}10.9 \% \\
(26)\end{array}$ & $\begin{array}{l}\text { Student 265: "[My anxiety is lower } \\
\text { in online science courses, } \\
\text { because] I don't have to have } \\
\text { my webcam on or speak if I } \\
\text { don't want to." }\end{array}$ & $\begin{array}{l}\text { Student 1349: "[My anxiety is } \\
\text { lower in online science } \\
\text { courses because] no one } \\
\text { can see me and I feel more } \\
\text { comfortable." }\end{array}$ \\
\hline
\end{tabular}

a Of the 241 students who reported having lower anxiety online compared with in person, 239 students answered the open-ended question about why their anxiety was higher in this environment. In the table, we highlight themes reported by at least $10 \%$ of students. Additional themes reported by at least $5 \%$ of students are reported in the Supplemental Material. 
TABLE 4. The most common reasons why students report the same amount of anxiety in large-enrollment college science courses compared with in-person courses ${ }^{a}$

\begin{tabular}{|c|c|c|c|c|}
\hline Category & Category description & $\begin{array}{c}\%(n) \\
N=290\end{array}$ & Example student response & Example student response \\
\hline $\begin{array}{l}\text { Anxiety is the same for the } \\
\text { same reasons in both } \\
\text { online and in-person } \\
\text { courses. }\end{array}$ & $\begin{array}{l}\text { Student describes that their anxiety is } \\
\text { the same both in person and online } \\
\text { for the same reasons. }\end{array}$ & $\begin{array}{l}52.1 \% \\
(151)\end{array}$ & $\begin{array}{l}\text { Student 597: "I feel the } \\
\text { environment and the } \\
\text { learning atmosphere are } \\
\text { pretty similar." }\end{array}$ & $\begin{array}{l}\text { Student 939: "Mainly for me, } \\
\text { the atmosphere remains } \\
\text { genuinely the same both } \\
\text { online and in person." }\end{array}$ \\
\hline $\begin{array}{l}\text { Anxiety is the same for differ- } \\
\text { ent reasons in both online } \\
\text { and in-person courses. }\end{array}$ & $\begin{array}{l}\text { Student describes that their anxiety is } \\
\text { the same both in person and online } \\
\text { but for different reasons. Also, } \\
\text { student describes there are different } \\
\text { pros and cons for in-person and } \\
\text { online courses, but the pros and } \\
\text { cons balance one another out. }\end{array}$ & $\begin{array}{c}23.4 \% \\
(68)\end{array}$ & $\begin{array}{l}\text { Student 1249: "Online } \\
\text { courses have different } \\
\text { stressors compared with } \\
\text { in-person classes, } \\
\text { however, my overall } \\
\text { anxiety levels are about } \\
\text { the same for each." }\end{array}$ & $\begin{array}{l}\text { Student 496: "It's more } \\
\text { difficult doing classes } \\
\text { online, but you can } \\
\text { rewatch lectures and you } \\
\text { have more time since you } \\
\text { aren't commuting so it } \\
\text { balances out." }\end{array}$ \\
\hline $\begin{array}{l}\text { Anxiety is the same for } \\
\text { personal reasons in both } \\
\text { online and in-person } \\
\text { courses. }\end{array}$ & $\begin{array}{l}\text { Student describes that their anxiety is } \\
\text { the same both in person and online } \\
\text { due to personal reasons, such as } \\
\text { having generally high or low } \\
\text { anxiety. }\end{array}$ & $\begin{array}{c}19.7 \% \\
(57)\end{array}$ & $\begin{array}{l}\text { Student 211: "I am always } \\
\text { anxious about every- } \\
\text { thing." }\end{array}$ & $\begin{array}{l}\text { Student 742: "I have little to } \\
\text { no anxiety in online } \\
\text { courses or in-person } \\
\text { courses." }\end{array}$ \\
\hline
\end{tabular}

${ }^{a}$ Of the 295 students who reported having the same amount of anxiety online compared with in person, 290 (98.3\%) students answered the open-ended question about why their anxiety was the same online and in person. All subthemes describing the reasons students experience the same amount of anxiety in online and in-person courses are included in the Supplemental Material.

(69.8\%), the use of proctored online exams (68.0\%), experiencing difficulty in getting to know other students in the class (67.2\%), feeling worried about accidentally causing a disruption during class $(66.8 \%)$, and needing to have their cameras on $(63.9 \%)$. Analyses yielded a number of significant demographic differences with regard to who was most likely to select particular factors related to large-enrollment online science courses that increase students' anxiety. All significant findings are reported in Table 5. The full result of each regression is reported in the Supplemental Material. Finding 4: Students Most Commonly Reported That Being
Able to Access Content at a Later Time, Attending Class
from Where They Want, and Not Having to Be on the
Camera Decreased Their Anxiety in Large-Enrollment
Online College Science Courses
Students most commonly selected that their anxiety in the context of large-enrollment online college science courses was decreased by being able to access content at a later time (79.0\%), being able to attend class from where they wanted (74.2\%), not having to be on camera (73.3\%), having increased test flexibility $(72.9 \%)$, and using informal discussion platforms such as WhatsApp and GroupMe to communicate with instructors and students (63.2\%). We identified a number of demographic differences with regard to who was more likely to select particular aspects of large-enrollment online science courses that decreased students' anxiety. All significant findings are reported in Table 6. The full result of each regression is reported in the Supplemental Material.

\section{Finding 5: Participants Identified Multiple Ways That Instructors Can Decrease Student Anxiety in Large-Enroll- ment Online College Science Courses, Including Increas- ing Test-Taking Flexibility, Being Understanding, and Having an Organized Course}

Analyzing student open-ended responses, we identified 10 ways that students commonly reported that instructors can alle- viate anxiety in their courses. The most frequently reported suggestion for what instructors of large-enrollment online college science courses could do to decrease student anxiety was to increase test-taking flexibility (25.0\%); participants specifically described allowing students to take non-proctored or open-note exams and removing time limits for exams. The second most frequently reported suggestion was for instructors to be flexible and understanding about students' unique situations and their mental health (23.1\%); students recommended that instructors demonstrate understanding by extending deadlines when needed or by not penalizing students when they experience technological issues. Nearly 15\% of students recommended that instructors could reduce student anxiety by providing an organized course. Students specifically suggested providing a full schedule of assignments and their corresponding deadlines, setting clear class expectations, and providing easily accessible class resources (e.g., Zoom links). Students also recommended that instructors be available and try to develop student-instructor relationships (13.0\%). Students highlighted that instructors could create more avenues for student-instructor communication, whether it be through emails, office hours, or sharing information to help students learn more about their instructors. Further, students also suggested that instructors should allow camera use to be optional (9.9\%), provide additional study materials (8.7\%), allow students to rewatch recorded lectures (8.5\%), facilitate the development of relationships among students (7.3\%), decrease the opportunities for group work (5.7\%), and decrease the course workload or slow down instruction (5.5\%). An additional 5.3\% of students reported that they perceive their instructors are doing the best they can to accommodate students' needs in their online course. All recommendations reported by at least $5 \%$ of students are recorded in Table 7 with example quotes.

\section{DISCUSSION}

In this study, we examined undergraduate student anxiety in the context of large-enrollment online college science courses, 
TABLE 5. Percent of students who selected each factor that increased their anxiety in large-enrollment online college science courses and a summary of any significant demographic differences of students who selected each factor ${ }^{\mathrm{a}}$

\begin{tabular}{lc}
\hline $\begin{array}{l}\text { Factors that can } \\
\text { increase student } \\
\text { anxiety }\end{array}$ & $\%(n)$ \\
$(N=2111)$ & Significant demographic differences $^{\mathrm{b}}$ \\
\hline
\end{tabular}

The potential for personal technology issues (e.g., unstable Internet connection)

Proctored online exams

Difficulty getting to know other students in the class

Worrying about causing an accidental disruption (e.g., accidentally unmuting yourself)

Needing to have my camera on

Disengaged students in breakout groups

Difficulty getting help from the instructor

Difficulty getting help from other students in class

Difficulty getting to know the instructor

Disorganized online course format
$69.8 \%$ Women had $1.6 \times$ higher odds of selecting this than men.

(1473) Latinx students had 1.6x higher odds of selecting this than white students.

For every one point increase in a student's GPA, they had $1.3 \times$ higher odds of selecting this.

Students with moderate anxiety had $1.7 \times$ higher odds and students with severe anxiety had $2.9 \times$ higher odds of selecting this than students with mild to no anxiety.

$68.0 \%$ Women had $1.4 \times$ higher odds of selecting this than men.

(1435) Latinx students had $1.5 \times$ higher odds of selecting this than white students.

Students who have more online learning experience had $1.3 \times$ higher odds of selecting this than students with less online experience.

Students with moderate anxiety had $2.6 \times$ higher odds and students with severe anxiety had $4.4 \times$ higher odds of selecting this than students with mild to no anxiety.

White students had $1.8 \times$ higher odds of selecting this than Black students.

Continuing-generation students had $1.4 \times$ higher odds of selecting this than first-generation students.

Lowerclassmen had $2.1 \times$ higher odds of selecting this than upperclassmen.

Students with moderate anxiety had $2.2 \times$ higher odds and students with severe anxiety had $3.7 \times$ higher odds of selecting this than students with no to mild anxiety.

$66.8 \%$ Women had $1.6 \times$ higher odds of selecting this than men.

(1410) White students had $1.8 \times$ higher odds of selecting this than Black students.

LGBTQ+ students had 2.0 $\times$ higher odds of selecting this than non-LGBTQ+ students.

Students with moderate anxiety had $1.8 \times$ higher odds and students with severe anxiety had $2.6 \times$ higher odds of selecting this than students with mild to no anxiety.

$63.9 \%$ Women had $1.6 \times$ higher odds of selecting this than men.

(1348) Latinx students had $1.5 \times$ higher odds of selecting this than white students.

Students who are not financially stable had $1.7 \times$ higher odds and students who are sometimes

financially stable had $1.4 \times$ higher odds of selecting this than financially stable students.

STEM majors had $1.6 \times$ higher odds of selecting this than non-STEM majors.

Students with severe anxiety had $2.3 \times$ higher odds of selecting this than students with mild to no anxiety.

Students with depression had $1.4 \times$ higher odds of selecting this than students without depression.

$63.1 \%$ Women had $1.4 \times$ higher odds of selecting this than men.

(1332) First-generation students had $1.4 \times$ higher odds of selecting this than continuing-generation students.

LGBTQ+ students had $1.5 \times$ higher odds of selecting this than non-LGBTQ+ students.

Lowerclassmen had $1.7 \times$ higher odds of selecting this than upperclassmen.

Students with more experience in online courses had $1.4 \times$ higher odds of selecting this than students with less online class experience.

For every one point increase in GPA, a student had $1.3 \times$ higher odds of selecting this.

Students with moderate anxiety had $1.9 \times$ higher odds and students with severe anxiety had $3.5 \times$ higher odds of selecting this than students with mild to no anxiety.

$59.2 \% \quad$ White students had $2.1 \times$ higher odds of selecting this than Black students.

(1250) Lowerclassmen had 1.6x higher odds of selecting this than upperclassmen.

Students with moderate anxiety had $2.7 \times$ higher odds and students with severe anxiety had $4.6 \times$ higher odds of selecting this than students with mild to no anxiety.

$58.3 \%$ Lowerclassmen had $1.4 \times$ higher odds of selecting this than upperclassmen.

(1231) Students with moderate anxiety had $2.4 \times$ higher odds and students with severe anxiety had $4.5 \times$ higher odds of selecting this than students with mild to no anxiety.

$57.2 \% \quad$ Lowerclassmen had $1.4 \times$ higher odds of selecting this than upperclassmen.

(1208) Students with more experience in online courses had $1.4 \times$ higher odds of selecting this than students with less online class experience.

For every one point increase in GPA, a student had $1.4 \times$ higher odds of selecting this.

Students with moderate anxiety had 2.6x higher odds and students with severe anxiety had 5.0 $\times$ higher odds of selecting this than students with mild to no anxiety.

Students with depression had $1.3 \times$ higher odds of selecting this than students without depression.

$55.5 \% \quad$ Upperclassmen had $1.3 \times$ higher odds of selecting this than lowerclassmen.

(1171) Students with more online experience had $1.3 \times$ higher odds of selecting this than students with less online experience.

Students with moderate anxiety had $2.2 \times$ higher odds and students with severe anxiety had $3.4 \times$ higher odds of selecting this than students with mild to no anxiety. 
TABLE 5. Continued

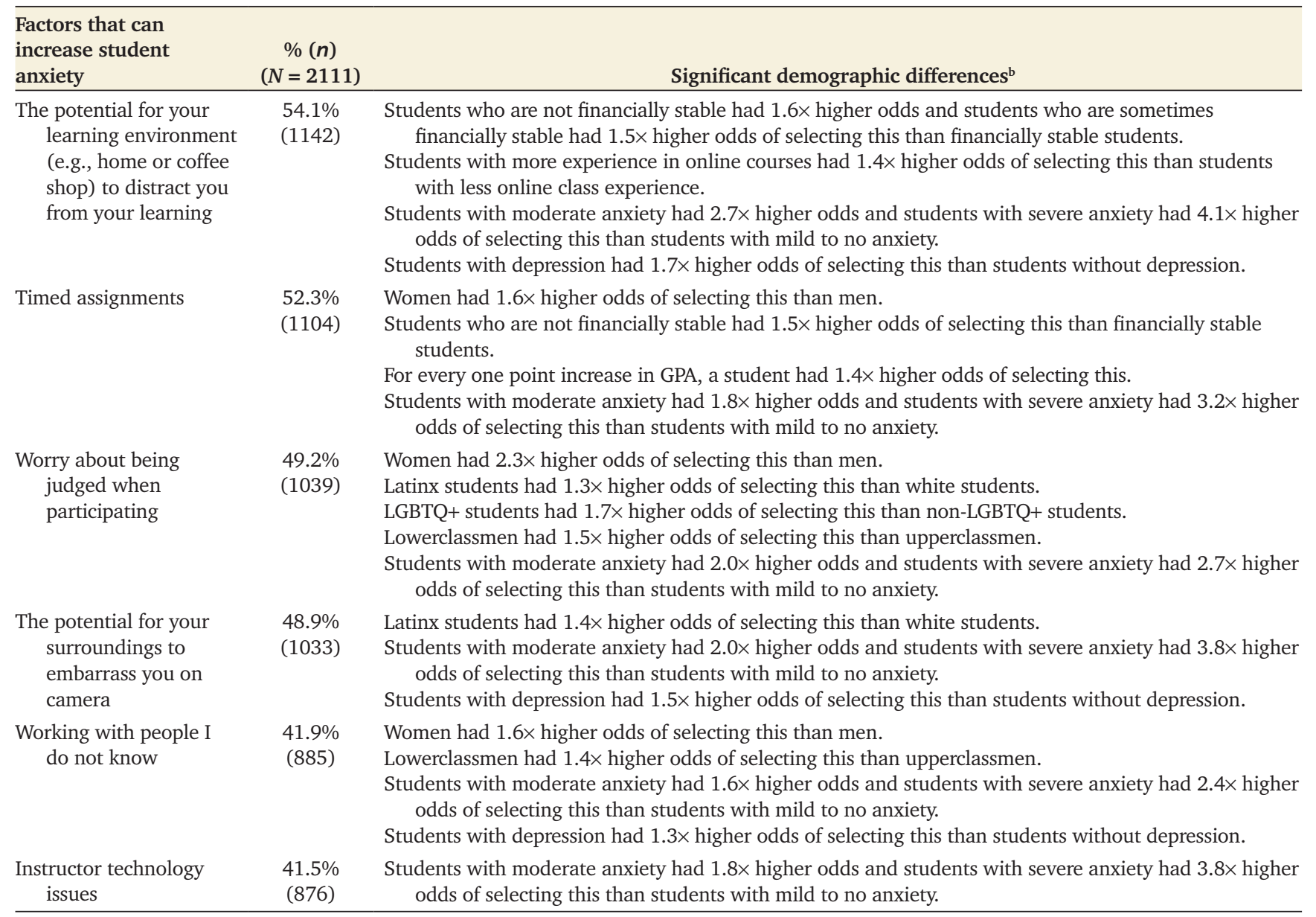

${ }^{a}$ Of the 2111 students who answered this question, $2.8 \%$ of students selected the response that nothing related to online courses increased their anxiety. bFor each factor, we conducted a logistic regression to test whether there were demographic differences in who reported each factor. The full result of each regression is reported in the Supplemental Material.

specifically, how student anxiety online compares with anxiety during in-person courses, what aspects of online science courses increase and decrease student anxiety, and what instructors can do to try and decrease student anxiety. We also probed whether student demographics predicted their anxiety levels and what aspects of large-enrollment online college science courses affected their anxiety. A summary of the main findings is presented in Figure 3.

\section{Anxiety in Large-Enrollment Online Science Courses during the COVID-19 Pandemic}

Of the 2111 students who were enrolled in at least one large-enrollment online science course, we found that a substantial number of students reported experiencing moderate $(37.2 \%)$ and severe (13.9\%) levels of anxiety. Women, financially unstable students, and those with depression were disproportionately more likely to report higher anxiety in the context of online science courses compared with men, financially stable students and those without depression, respectively. While women (Misra and McKean, 2000; Bayram and Bilgel, 2008), individuals who are financially unstable (Eisenberg et al., 2007), and those with depression (Eisenberg et al., 2007; Mah- moud et al., 2012) have been found to have higher generalized anxiety than their counterparts, there is evidence that the online environment may further exacerbate or contribute to these gaps. For example, women generally report feeling more anxious about taking courses online compared with men (Saadé et al., 2017), and grade disparities between men and women are greater in online STEM courses compared with in-person courses (Mead et al., 2020). Additionally, studies show that online science coursework could present challenges for students with depression because of the difficulties students experience developing relationships with students and instructors online, the lack of a need to show up somewhere in person, and the self-paced nature of online courses (Gin et al., 2021a; Mohammed et al., unpublished data). Online courses likely also present unique challenges for students who are not financially stable, including the need for high-speed Internet access and quiet workspaces (Venegas, 2007; Aguilar et al., 2020). Working to decrease student anxiety in online science may be integral to promoting a more diverse and inclusive scientific community, given the underrepresentation of women, those coming from low-socioeconomic backgrounds, and individuals with disabilities (such as depression) in the sciences. 
TABLE 6. Percent of students who selected each factor that decreased their anxiety in large-enrollment online college science courses and a summary of any demographic differences of students who selected each factor

\begin{tabular}{|c|c|c|}
\hline $\begin{array}{l}\text { Factors that can decrease } \\
\text { student anxiety }\end{array}$ & $\begin{array}{c}\%(n) \\
(N=2111)\end{array}$ & Significant demographic differences ${ }^{b}$ \\
\hline $\begin{array}{l}\text { Being able to access content at a } \\
\text { later time (e.g., rewatch a } \\
\text { lecture video) }\end{array}$ & $\begin{array}{l}79.0 \% \\
(1667)\end{array}$ & $\begin{array}{l}\text { Women had } 1.7 \times \text { higher odds of selecting this than men. } \\
\text { Upperclassmen had } 1.5 \times \text { higher odds of selecting this than lowerclassmen. } \\
\text { Students with more experience in online courses had } 1.6 \times \text { higher odds of selecting this } \\
\text { than students with less online class experience. } \\
\text { STEM majors had } 1.5 \times \text { higher odds of selecting this than non-STEM majors. } \\
\text { Students with mild to no anxiety had } 1.7 \times \text { higher odds of selecting this than students with } \\
\text { severe anxiety. } \\
\text { Students with depression had } 1.5 \times \text { higher odds of selecting this than students without } \\
\text { depression. }\end{array}$ \\
\hline
\end{tabular}

The flexibility of attending class $\quad 74.2 \%$ where I want

(1567)

Not having to be on camera

Increased test flexibility (e.g., open-note, open for a long time)

The use of informal discussion platforms such as WhatsApp, GroupMe, Discord, or Slack

The flexibility of attending class when I want

Instructor cares about student concerns

Student groups that are preassigned (not having to find my own group to work in)

When getting help from the instructor is easy

Clear instruction from instructor about how to communicate in class
Women had $1.4 \times$ higher odds of selecting this than men.

Students with mild to no anxiety had $1.4 \times$ higher odds of selecting this than students with moderate anxiety and had $2.0 \times$ higher odds of selecting this than students with severe anxiety.

Students with depression had $1.3 \times$ higher odds of selecting this than students without depression.

Women had $1.7 \times$ higher odds of selecting this than men.

Latinx students had $1.4 \times$ higher odds of selecting this than white students.

Students with mild to no anxiety had $1.5 \times$ higher odds of selecting this than students with severe anxiety.

Students with depression had $1.3 \times$ higher odds of selecting this than students without depression.

Women had $1.4 \times$ higher odds of selecting this than men.

LGBTQ+ students had 1.6× higher odds of selecting this than non-LGBTQ+ students.

Students who are sometimes financially stable had 1.4× higher odds of selecting this than students who are financially stable.

Students with mild to no anxiety had $1.6 \times$ higher odds of selecting this than students with severe anxiety.

Students with more experience in online courses had $1.4 \times$ higher odds of selecting this than students with less online class experience.

$63.2 \% \quad$ Women had $1.4 \times$ higher odds of selecting this than men.

(1335) Lowerclassmen had $1.5 \times$ higher odds of selecting this than upperclassmen.

54.9\% Upperclassmen had 1.4× higher odds of selecting this than lowerclassmen.

(1159) Students with more experience in online courses had $1.3 \times$ higher odds of selecting this than students with less online class experience.

Students with mild to no anxiety had $1.4 \times$ higher odds of selecting this than students with severe anxiety.

Women had $2.1 \times$ higher odds of selecting this than men.

Women had $2.1 \times$ higher odds of selecting this than men.

Lowerclassmen had $1.7 \times$ higher odds of selecting this than upperclassmen.

Students with mild to no anxiety had $1.3 \times$ higher odds of selecting this than students with moderate anxiety and had $1.9 \times$ higher odds of selecting this than students with severe anxiety.

First-generation college students had $1.3 \times$ higher odds of selecting this than continuing-generation students.

Students with more experience in online courses had $1.3 \times$ higher odds of selecting this than students with less online class experience.

STEM majors had $1.4 \times$ higher odds of selecting this than non-STEM majors.

$44.7 \% \quad$ Women had $1.5 \times$ higher odds of selecting this than men.

(943) Students with mild to no anxiety had $1.5 \times$ higher odds of selecting this than students with severe anxiety. 
TABLE 6. Continued

\begin{tabular}{|c|c|c|}
\hline $\begin{array}{l}\text { Factors that can decrease } \\
\text { student anxiety }\end{array}$ & $\begin{array}{c}\%(n) \\
(N=2111)\end{array}$ & Significant demographic differences ${ }^{\mathrm{b}}$ \\
\hline $\begin{array}{l}\text { Having the ability to ask questions } \\
\text { to the instructor during class } \\
\text { without everyone seeing }\end{array}$ & $\begin{array}{l}41.1 \% \\
(868)\end{array}$ & $\begin{array}{l}\text { Women had } 1.8 \times \text { higher odds of selecting this than men. } \\
\text { Latinx students had } 1.5 \times \text { higher odds of selecting this than white students. } \\
\text { Students who are not financially stable had } 1.5 \times \text { higher odds of selecting this than } \\
\text { students who are financially stable. } \\
\text { Lowerclassmen had } 1.3 \times \text { higher odds of selecting this than upperclassmen. } \\
\text { Students with mild to no anxiety had } 1.6 \times \text { higher odds of selecting this than students with } \\
\text { severe anxiety. } \\
\text { Students with depression had } 1.6 \times \text { higher odds of selecting this than students without } \\
\text { depression. }\end{array}$ \\
\hline $\begin{array}{l}\text { When getting help from people in } \\
\text { class is easy }\end{array}$ & $\begin{array}{l}40.6 \% \\
(858)\end{array}$ & Lowerclassmen had $1.3 \times$ higher odds of selecting this than upperclassmen. \\
\hline $\begin{array}{l}\text { When work does not have } \\
\text { deadlines and just needs to be } \\
\text { completed by the end of the } \\
\text { semester }\end{array}$ & $\begin{array}{c}33.3 \% \\
(704)\end{array}$ & $\begin{array}{l}\text { Asian students had } 1.5 \times \text { higher odds of selecting this than white students. } \\
\text { Students who are not financially stable had } 1.5 \times \text { higher odds of selecting this than } \\
\text { students who are financially stable. } \\
\text { Students with depression had } 1.3 \times \text { higher odds of selecting this than students without } \\
\text { depression. }\end{array}$ \\
\hline $\begin{array}{l}\text { Clear instruction from instructor } \\
\text { about how to communicate } \\
\text { with other students in class }\end{array}$ & $\begin{array}{l}30.1 \% \\
(635)\end{array}$ & $\begin{array}{l}\text { Women had } 1.3 \times \text { higher odds of selecting this than men. } \\
\text { First-generation college students had } 1.4 \times \text { higher odds of selecting this than continu- } \\
\text { ing-generation students. } \\
\text { Students with depression had } 1.3 \times \text { higher odds of selecting this than students without } \\
\text { depression. }\end{array}$ \\
\hline $\begin{array}{l}\text { Not having to contact the } \\
\text { instructor in person }\end{array}$ & $\begin{array}{c}24.4 \% \\
(515)\end{array}$ & $\begin{array}{l}\text { Women had } 1.7 \times \text { higher odds of selecting this than men. } \\
\text { LGBTQ+ students had } 1.6 \times \text { higher odds of selecting this than non-LGBTQ+ students. }\end{array}$ \\
\hline $\begin{array}{l}\text { Being able to use the greenscreen } \\
\text { to change your Zoom } \\
\text { background }\end{array}$ & $\begin{array}{l}9.9 \% \\
(210)\end{array}$ & $\begin{array}{l}\text { Black students had } 2.5 \times \text { higher odds of selecting this than white students. } \\
\text { Latinx students had } 2.0 \times \text { higher odds of selecting this than white students. }\end{array}$ \\
\hline
\end{tabular}

${ }^{a}$ Of the 2111 students who answered this question, $2.6 \%$ of students reported that nothing related to online courses decreases their anxiety.

bor each factor, we conducted a logistic regression to test whether there were demographic differences in who reported each factor. The full result of each regression is reported in the Supplemental Material.

When students were asked if they perceived experiencing higher, lower, or the same anxiety as in-person courses, we found that students most commonly reported experiencing higher anxiety in their online science courses. Disproportionate numbers of students with depression and those with higher GPAs reported higher anxiety online. This finding is supported by previous literature suggesting that online courses can be more anxiety inducing than in-person courses (DeVaney, 2010; Stowell and Bennett, 2010). When asked to explain why learning online caused students higher anxiety compared with in person, students most commonly reported that they perceived learning to be more difficult online as well as it being more difficult for them to stay engaged and on top of their assign- ments. Students may be perceiving it is more difficult for them to learn and stay on top of their assignments because online learning is typically associated with high self-regulation (Kauffman, 2015) and self-discipline (Waschull, 2005; Gorbunovs et al., 2016). However, it should be noted that, even though students generally perceive learning online to be more difficult, it is unclear whether students learn more in online or in-person courses (Biel and Brame, 2016). Out of the studies that have controlled for academic ability in addition to other predictive factors of performance, such as gender and race/ethnicity, two have shown no difference in student learning outcomes measured by grades between students enrolled in online and in-person courses (Peterson and Bond, 2004; 
TABLE 7. The most common suggestions students reported for how instructors can decrease anxiety among undergraduates in online college science courses ${ }^{\mathrm{a}}$

\begin{tabular}{|c|c|c|c|c|}
\hline Category & Category description & $\begin{array}{l}\%(n) \\
N=563\end{array}$ & Example student response & Example student response \\
\hline $\begin{array}{l}\text { Increase test-taking } \\
\text { flexibility. }\end{array}$ & $\begin{array}{l}\text { Student describes that instructors can } \\
\text { help decrease student anxiety by } \\
\text { allowing more flexibility when } \\
\text { taking exams online (e.g., open } \\
\text { notes, nonproctored, or no time } \\
\text { limits). }\end{array}$ & $\begin{array}{l}25.0 \% \\
(141)\end{array}$ & $\begin{array}{l}\text { Student 961: "Not having the } \\
\text { test proctored and [allowing] } \\
\text { longer [test] times. Trust us } \\
\text { students without giving us } \\
\text { the anxiety we already } \\
\text { have." }\end{array}$ & $\begin{array}{l}\text { Student 337: "[Instructors } \\
\text { could] stop using creepy } \\
\text { proctoring software [for } \\
\text { exams]. If you must } \\
\text { proctor exams, just do so } \\
\text { live over Zoom." }\end{array}$ \\
\hline $\begin{array}{l}\text { Be flexible and } \\
\text { understanding. }\end{array}$ & $\begin{array}{l}\text { Student describes that instructors can } \\
\text { help decrease student anxiety by } \\
\text { being more flexible and understand- } \\
\text { ing of unforeseen issues students }\end{array}$ & $\begin{array}{l}23.1 \% \\
(130)\end{array}$ & $\begin{array}{l}\text { Student 1937: "[Increased] } \\
\text { flexibility, whether it be } \\
\text { regarding technology, } \\
\text { attendance, lectures, }\end{array}$ & $\begin{array}{l}\text { Student 623: "[Instructors } \\
\text { can] avoid penalizing } \\
\text { students for tech issues [to } \\
\text { reduce student anxiety]." }\end{array}$ \\
\hline
\end{tabular}

Have an organized course.

Be available and try to develop studentinstructor relationships.
Student describes that instructors can help decrease student anxiety by setting clear class expectations and outlining course content.

$14.7 \%$ may experience online and when students may be struggling with their mental health.

assignments, etc. [can help]

greatly decrease [student] anxiety. Many unforeseen things happen during a given week [that can cause] anxiety."

Student 1959: "[Instructors] could set up a schedule that lays out everything the students need to get done, instead of leaving it up to the individual students." describes that instructors help decrease student anxiety by creating more avenues for studentinstructor communication.
Allow cameras to be optional.
Student describes that instructors can help reduce student anxiety by not requiring students to have their cameras on.
Provide additional study materials.

Provide opportunities to rewatch lectures.
Student describes that instructors can help reduce student anxiety by facilitating or encouraging student study groups and providing additional test preparation materials.

Student describes that instructors can help reduce student anxiety by providing video recordings of lectures, so that students can rewatch/listen to them when they want/need to.
Student 1605: "At the beginning of the semester, instructors should introduce themselves and tell students a little about themselves when they are not teaching. This helps students and the professor make a connection [to alleviate student anxiety]."

Student 185: "I think [instructors] just being understanding that students may not feel comfortable having their camera on and may not always have access to a quiet environment that promotes learning [helps reduce student anxiety]."

Student 1355: "I think [instructors could] assign student study groups [to reduce student anxiety]."

Student 1559: "[Instructors can] post recordings of lectures on Canvas for students to view. There are a lot of students who cannot focus during class due to their environment and for those who have Internet issues."
Student 2080: "Professors need to be more explicit on grading, exam formats, and such ahead of time."

Student 160: "Poll students more often so that they can get feedback as well to see what's been working and what hasn't, and how they feel about certain formats, especially in regards to exams and lectures."

Student 769: "[Instructors can] allow not having the camera be mandatory, especially since lower-income students may not be able to attend class in a quiet, clean room."

Student 2120: "[Instructors can] give us practice problems similar to the ones on tests and going [sic] through them with us."

Student 331: "Watching a professor speak to a computer is oftentimes significantly less engaging than in person, thus, when possible, [instructors] should allow students to watch [lectures] at their own time and video pace in order to learn more efficiently." 


\begin{tabular}{|c|c|c|c|c|}
\hline Category & Category description & $\begin{array}{l}\%(n) \\
N=563\end{array}$ & Example student response & Example student response \\
\hline $\begin{array}{l}\text { Facilitate opportunities } \\
\text { to build relation- } \\
\text { ships among } \\
\text { students. }\end{array}$ & $\begin{array}{l}\text { Student describes that instructors can } \\
\text { help decrease student anxiety by } \\
\text { creating opportunities for students } \\
\text { to get to know each other. }\end{array}$ & $\begin{array}{l}7.3 \% \\
(41)\end{array}$ & $\begin{array}{l}\text { Student 1757: "[Instructors can } \\
\text { reduce student anxiety by } \\
\text { having] a class day devoted } \\
\text { to making personal } \\
\text { connections with [other] } \\
\text { students and not just the } \\
\text { teacher and TA's." }\end{array}$ & $\begin{array}{l}\text { Student 1292: "Maybe assign } \\
\text { a buddy per class at the } \\
\text { start of the semester. I } \\
\text { would think that would } \\
\text { help [student anxiety]." }\end{array}$ \\
\hline $\begin{array}{l}\text { Fewer breakout rooms } \\
\text { or opportunities for } \\
\text { group work }\end{array}$ & $\begin{array}{l}\text { Student describes that instructors can } \\
\text { help decrease student anxiety by not } \\
\text { having breakout rooms or less group } \\
\text { work. }\end{array}$ & $\begin{array}{l}5.7 \% \\
(32)\end{array}$ & $\begin{array}{l}\text { Student 1624: "[Instructors can } \\
\text { decrease anxiety by having] } \\
\text { less [sic] breakout rooms } \\
\text { because there is little } \\
\text { participation. I don't like that } \\
\text { my education relies on the } \\
\text { participation of others." }\end{array}$ & $\begin{array}{l}\text { Student 1017: "[Instructors } \\
\text { could decrease student } \\
\text { anxiety by having] fewer } \\
\text { breakout rooms because } \\
\text { most people don't want to } \\
\text { be the first to start } \\
\text { talking." }\end{array}$ \\
\hline $\begin{array}{l}\text { Decrease workload or } \\
\text { slow the pace of the } \\
\text { course. }\end{array}$ & $\begin{array}{l}\text { Student describes that instructors can } \\
\text { help decrease student anxiety by } \\
\text { assigning fewer assignments or } \\
\text { slowing down the instruction. }\end{array}$ & $\begin{array}{l}5.5 \% \\
(31)\end{array}$ & $\begin{array}{l}\text { Student 112: "Don't pile on } \\
\text { more work because you } \\
\text { think we can take it since } \\
\text { we're home; the only thing } \\
\text { that has changed is our } \\
\text { location, not our schedules." }\end{array}$ & $\begin{array}{l}\text { Student 377: "[Instructors can } \\
\text { decrease student anxiety } \\
\text { by not] assigning too } \\
\text { many assignments at } \\
\text { once." }\end{array}$ \\
\hline $\begin{array}{l}\text { No suggestions, } \\
\text { professor is doing } \\
\text { everything they } \\
\text { can. }\end{array}$ & $\begin{array}{l}\text { Student describes that they have no sug- } \\
\text { gestions for how instructors can help } \\
\text { decrease student anxiety and } \\
\text { acknowledges instructors are doing } \\
\text { the best they can. }\end{array}$ & $\begin{array}{l}5.3 \% \\
(30)\end{array}$ & $\begin{array}{l}\text { Student 1273: "I feel like my } \\
\text { professors at least have been } \\
\text { very understanding and } \\
\text { doing the most they can } \\
\text { despite the circumstances." }\end{array}$ & $\begin{array}{l}\text { Student 1257: "I do not have } \\
\text { any suggestions, for me, it } \\
\text { seems to be working great } \\
\text { so far." }\end{array}$ \\
\hline
\end{tabular}

a Of the 634 students asked to suggest in what ways instructors can help decrease student anxiety, 563 (88.8\%) students answered the open-ended question and 74 (13.1\%) student responses were unable to be coded in one of the categories described above.

Cavanaugh and Jacquemin, 2015), while one found that students received higher grades in in-person courses (Mead et al., 2020). Yet notably, in a large-scale study of more than 25,000 student-course enrollments at the institution where our study was conducted, researchers found that when in-person students were enrolled in online courses during the COVID-19 pandemic (as they were in the current study), students perceived that they learned less in online courses, despite receiv-

\begin{tabular}{|c|c|}
\hline $\begin{array}{l}\text { Most commonly reported factors that } \\
\text { increase student anxiety in online courses }\end{array}$ & $\begin{array}{l}\text { Most commonly reported factors that } \\
\text { decrease student anxiety in online courses }\end{array}$ \\
\hline $\begin{array}{l}\text { 1. The potential for personal technology } \\
\text { issues (e.g., unstable internet connection) } \\
\text { 2. Proctored online exams } \\
\text { 3. Difficulty getting to know other students in } \\
\text { the class }\end{array}$ & $\begin{array}{l}\text { 1. Being able to access content at a later time } \\
\text { (e.g., re-watch a lecture video) } \\
\text { 2. The flexibility of attending class where the } \\
\text { student wants } \\
\text { 3. Not having to be on camera }\end{array}$ \\
\hline \multicolumn{2}{|c|}{$\begin{array}{l}\text { Most commonly reported suggestions for how instructors } \\
\text { can decrease student anxiety in online courses }\end{array}$} \\
\hline $\begin{array}{l}\text { 1. Increase test-taking flexibility } \\
\text { 2. Be flexible and understanding } \\
\text { 3. Have an organized course } \\
\text { 4. Be available and make an effort to devel } \\
\text { 5. Allow cameras to be optional }\end{array}$ & udent-instructor relationships \\
\hline
\end{tabular}

FIGURE 3. Summary of primary findings including the most commonly selected factors that increase and decrease student anxiety in online courses as well as the most commonly reported student-generated suggestions for instructors who want to decrease student anxiety in large-enrollment online college science courses. ing higher grades (Supriya et al., 2021). Regardless of whether students actually learn more in online versus in-person science courses, providing students with information about how to self-regulate and improve their motivation, and subsequently reduce their anxiety, may help them adjust to online learning.

We also acknowledge that, while students were asked specifically about their anxiety in the specific context of online college science courses, the COVID-19 pandemic, racial unrest and racially driven hate crimes, and political unrest likely contributed to many students' emotions and evaluation of their experiences of online versus in-person courses (Chou et al., 2012; Kecojevic et al., 2020; Ni et al., 2020).

\section{Factors Associated with Online College Science Courses and the Dispropor- tionate Impact They May Have on Students in Different Demographic Groups}

In attempts to continue building a more inclusive and welcoming community for students of diverse backgrounds, it is important to identify whether specific aspects of online college science courses disproportionately affect particular demographic groups of students. In the 
following sections, we discuss what aspects of online education may disproportionately contribute to students' anxiety based on their demographics.

Gender. In our analyses, which controlled for anxiety level in online college science courses, women were more likely than men to select that their anxiety was impacted by many of the social aspects of online science courses. For example, we found that women were more likely than men to report that being on camera contributed to their anxiety. This may be partially explained by women being more consciously aware of their physical appearance (Choukas-Bradley et al., 2019; Castelli and Sarvary, 2021), combined with the notion that negative appraisals related to physical characteristics have been correlated with lower self-evaluations of social competence (Gibson and Thomas, 1991). This may also explain why women were more likely to report that not having to use their cameras and the ability to conceal parts of their identity online decreased their anxiety. Further, women were more likely than men to report that the possibility of accidentally causing an unwanted disruption during class and the fear of being judged when participating online increased their anxiety. While studies have shown that fear of negative evaluation, or the sense of dread associated with being unfavorably evaluated while participating in a social situation, is a common factor underlying student anxiety in science classrooms (Cooper et al., 2018a; Cooper and Brownell, 2020; Downing et al., 2020), this is the first quantitative study to suggest that fear of negative evaluation may disproportionately affect women. However, these findings relate to previous studies showing that women are disproportionately likely to have mindsets associated with achieving perfectionism (Davis et al., 2001), yet also more likely to have a low academic self-concept or lower perceptions of their abilities in academic domains compared with men, even when they have equivalent GPAs (Cooper et al., 2018b). Additionally, we found that women were more likely than men to report that being in a breakout room with people they do not know or working with students who were disengaged heightened their anxiety. This may be because women put a greater emphasis on interpersonal ways of communication (McKeachie et al., 1966), with a preference to work in proximity with colleagues to receive direct support (Lee and Robbins, 2000). Moreover, working with a friend has been shown to be a predictor of student comfort in group work in college biology courses, which in turn predicts students' content mastery (Theobald et al., 2017), and women students in particular perceive less value in group work when they do not have a friend in the group (Eddy et al., 2015). As such, women were more likely than men to select pre-assigned student groups and to select that using informal discussion platforms in online science courses as factors that decreased their anxiety. These findings suggest that women are disproportionately impacted by some of the social aspects of online courses.

Race/Ethnicity. Students' race/ethnicity also predicted what factors increased and decreased their anxiety in large-enrollment online college science courses; particularly, notable differences emerged between Latinx and non-Latinx white students. Latinx students were more likely than white students to select that their anxiety was impacted by aspects of online science courses related to privacy. For example, we found that Latinx students were more likely than white students to report having the camera on and specifically the possibility of their surroundings embarrassing them while on camera as factors that increased their anxiety. One hypothesis for why this may be is that Latinx households are associated with high levels of family engagement (Telzer and Fuligni, 2009), where it may be possible that ongoing family presence can lead to potential unwanted disruption during class time. In fact, a recent study showed that underrepresented minority students (a group that included Latinx students) reported that they sometimes did not turn their camera on because they were concerned about others being seen behind them (Castelli and Sarvary, 2021). This may also explain why Latinx students were more likely than non-Latinx white students to report that proctored exams increase their anxiety, as students may be penalized for interruptions that may occur while taking an exam. We also found that Latinx students were more likely than white students to report having instructors that care about students' concerns as a factor that decreases their anxiety, which echoes a study that demonstrated that Latinx students value instructors who interact with students in caring ways (Newcomer, 2018). Therefore, we hypothesize that the third most commonly reported student recommendation to decrease student anxiety, having instructors make an effort to connect with students, may be especially beneficial for Latinx students.

Students with Depression. Following anxiety, depression is the second most commonly reported mental health concern among college students (Center for Collegiate Mental Health, 2021). As such, we were interested in how, if at all, students' depression predicted what factors affected their anxiety. We found that students with depression were more likely to report that needing to be on camera for class and the potential for their surroundings to embarrass them while on camera increased their anxiety. Literature has shown that students with depression value maintaining anonymity (Levine et al., 2003). One interview study of students with depression found that needing to be on camera during online course work can worsen students' depression because they cannot hide when they are feeling sad or upset (Mohammed et al., unpublished data), and undergraduates are often reluctant to reveal their depression to peers and mentors (Cooper et al., 2020c); the camera being on may be particularly detrimental when students are feeling sad or disengaged, making it harder for students to conceal their depression from others. Additionally, we found that students with depression were more likely than students without depression to report that being able to access content at a later time, having the flexibility of attending class where they want, and having assignments without deadlines decreased their anxiety. This may be because students with depression report difficulty focusing and staying motivated in academic environments (Orr, 2019; Cooper et al., 2020b; Gin et al., 2021c), which would make having access to content at any time helpful. Further, students with depression are prone to experiencing depressive episodes or periods of time when their depression is especially bad. During these times, it can be helpful for students to not have to leave their homes and to have the option of catching up on work at a later time (Judd et al., 2000; Cooper et al., 2020b). Students in this study highlighted that to decrease anxiety instructors could be more understanding of students' mental 
health concerns and more flexible, which may be particularly beneficial for students with depression.

LGBTQ+ Students. Science fields and college science courses can be particularly unfriendly toward LGBTQ+ individuals (Bilimoria and Stewart, 2009; Cech and Waidzunas, 2011; Patridge et al., 2014; Cooper and Brownell, 2016; Linley et al., 2018; Cooper et al., 2019). As such, it is not necessarily surprising that LGBTQ+ students were more likely than non-LGBTQ+ students to report that worrying about being judged increased their anxiety and that being able to conceal their identities online helped to alleviate their anxiety. Further, science faculty are known to hold less positive attitudes toward LGBTQ+ issues compared with faculty in other disciplines (Brown et al., 2004), which may help explain why LGBTQ+ students were more likely than their peers to report that not having to contact instructors in person decreased their anxiety. As such, not requiring students to keep their cameras on and reducing or eliminating the need for required verbal participation in front of the whole class may not only reduce student anxiety (Castelli and Sarvary, 2021; Cooper et al., 2021), but may be disproportionately helpful for LGBTQ+ students who do not feel safe or welcome in college science courses.

\section{Student Suggestions for Instructors about How to Reduce Anxiety in Large-Enrollment Online Science Courses}

Decreasing student anxiety can result in an increase in student motivation and performance (McKeachie, 1951; Culler and Holahan, 1980; Fletcher and Carter, 2010; Vitasari et al., 2010; England et al., 2017, 2019; Hood et al., 2021). Many of the strategies that students in this study identified to reduce anxiety in online college science courses are further supported by the literature and may provide instructors with effective ways of mitigating student anxiety. For example, test anxiety, defined as feelings of excessive worrying, nervousness, or irrelevant thinking during an assessment (Rasor and Rasor, 1998; Hancock, 2002; Chapell et al., 2005), is common among undergraduates (Hashmat et al., 2008), and students in this study highlight why online exams can be uniquely stressful due to proctoring software and technological challenges. Thus, eliciting student concerns about online exams and enacting changes to make exams less anxiety provoking may be important; studies have demonstrated that instructors who positively respond to students' concerns in an online context result in academic improvement, feelings of gratitude toward the instructor, and feelings of "having a voice" (Sitzman, 2016). Additionally, students highlighted the importance of online science instructors being understanding and flexible. Caring instructors in online education can help students feel more comfortable and appreciated, despite the lack of physical contact and proximity to the instructor (Leners and Sitzman, 2006). In general, positive student-instructor relationships have been found to be significant contributors to student learning, satisfaction, and belonging (Sher, 2009; Cooper et al., 2017a) and to decrease student academic dishonesty (Stearns, 2001). Further, students requested that instructors provide organized online science courses. Organization has been lauded as an essential element of online courses (Simon, 2000), given that online students often need to plan their personal schedules around their courses (Savery, 2005). As such, keeping course content organized and providing detailed and inclusive syllabi (Gin et al., 2021b) allow students to plan ahead when necessary, especially because most online students have important commitments outside school, such as work or family obligations (Harris and Martin, 2012). As college science courses continue to be increasingly delivered to students via online platforms, we encourage instructors to consider how small changes such as increasing communication with students and explicitly encouraging students could be impactful in reducing student anxiety and improving students' experiences in science courses.

\section{Limitations}

This study was conducted during the COVID-19 pandemic, when the science courses at this particular institution were being taught online. While this unique situation made this study possible, it also limits the generalizability of our findings. We made substantial effort to focus students' attention on their online science courses when they answered questions on the survey about their anxiety; however, it is possible that their responses may have been affected by other circumstances related to the COVID-19 pandemic, including increased financial and emotional strain. As such, these results may not be generalizable to students' experiences after the pandemic, and this work should be replicated after the pandemic is over. Additionally, this study was conducted at a large R1 institution and further research needs to examine whether the findings are generalizable to other institutional types. While we predict that some of the aspects of online courses that affect anxiety would be relevant in smaller courses of less than 100 students, participants in this study were asked to consider only large-enrollment science courses. Finally, this study relied on students' self-reporting; while self-report is an accurate way to gauge anxiety levels (Spitzer et al., 2006), students' perceptions of what increases and decreases their anxiety could be tested in future studies by measuring student anxiety before and after specific interventions. Finally, we chose not to correct for multiple testing based on the guideline offered by Wickens and Keppel (2004, p. 113). Specifically, given that each of our research questions was a principal driver of the study, questions are best considered in isolation. Hence, we fixed each test's per-comparison rate at $\alpha=0.05$, and no other adjustments were made.

\section{Conclusion}

In this study, we explored student anxiety in the context of large-enrollment online college science courses and found that students most commonly reported moderate levels of anxiety, and women, students who were not financially stable, and students with depression were significantly more likely to report higher levels of anxiety compared with their counterparts. On average, students report higher anxiety in their large-enrollment online college science courses compared with their large-enrollment in-person college science courses. Students with depression and students with higher GPAs were disproportionately likely to report having higher anxiety in large-enrollment online courses compared with in-person courses. Students most frequently reported having higher anxiety online because it was difficult to learn online, stay on top of their assignments, and make connections with other students. We also assessed what factors generally contributed to students' anxiety in their large-enrollment online college science courses. The most 
frequently reported factors that increase student anxiety online were technological issues, proctored exams, and difficulty getting to know other students. In contrast, being able to access content at a later time, the flexibility of attending class from where a student wants, and not having to be on camera were the most commonly reported factors that decrease students' anxiety in their large-enrollment online college science courses. Student gender, race/ethnicity, LGBTQ+ status, and whether or not they had depression commonly predicted what specific factors affected their anxiety. Finally, students identified 10 ways in which instructors can alleviate student anxiety in their courses, including increasing test-taking flexibility, being flexible and understanding, and having an organized course. This research provides concrete ways that instructors of large-enrollment college science courses can create more inclusive online learning environments for students with anxiety.

\section{Important Note}

If you or someone you know is struggling with anxiety, colleges and universities often provide resources, including walk-in and online counseling services. For more information, please visit the website of your local university health center for information about counseling and intervention services. Additionally, national mental health helplines and websites provide tips on managing anxiety. For example, the Substance Abuse and Mental Health Services Administration (SAMHSA) national helpline is free, confidential, and provides information service and treatment referral in English and Spanish 24/7, 365 days a year: 1-800-662-HELP (4357) or TTY: 1-800487-4889 (SAMHSA, 2021). The National Alliance on Mental Illness also offers support to people struggling with mental health Monday-Friday (10:00 am to 8:00 pm ET): 1-800-950NAMI (6264) or visit www.nami.org/help (NAMI, 2021). In addition, the National Institute of Mental Health, www.nimh .nih.gov/health/topics/anxiety-disorders/\#part_145338 (NIHM, 2021), offers reliable information about signs, symptoms, treatments, and therapies for anxiety disorders; you can contact the NIMH information resource center about mental health conditions at 1-(866)-615-6464.

\section{ACKNOWLEDGMENTS}

We would like to thank the instructors who were willing to distribute a survey about mental health among their students, and we are especially grateful to the students who agreed to participate in the study and shared their thoughts with us. We thank Rachel Scott for her review of an earlier draft of this article. J.G.W., C.V., and C.A.B are supported by National Science Foundation (NSF) Graduate Fellowships (DGE-1311230). This project was partially supported by the Howard Hughes Medical Institute (HHMI; GR35050). Any opinions, findings, conclusions, or recommendations expressed in this material are those of the authors and do not necessarily reflect the views of the NSF or HHMI.

\section{REFERENCES}

Abdous, M. (2019). Influence of satisfaction and preparedness on online students' feelings of anxiety. The Internet and Higher Education, 41, 34-44.

Adkins-Jablonsky, S. J., Shaffer, J. F., Morris, J. J., England, B., \& Raut, S (2021). A tale of two institutions: Analyzing the impact of gamified student response systems on student anxiety in two different introductory biology courses. CBE-Life Sciences Education, 20(2), ar19.
Agresti, A., \& Franklin, C. A. (2012). Statistics: The art and science of learning from data (Books a la Carte Edition) (3rd ed.). Upper Saddle River, NJ: Pearson.

Aguilar, S. J., Galperin, H., Baek, C., \& Gonzalez, E. (2020). When school comes home: How low-income families are adapting to distance learning. EdArXiv. https://doi.org/10.35542/osf.io/su8wk

Allen, I. E., \& Seaman, J. (2013). Changing course: Ten years of tracking online education in the United States. ERIC.

American College Health Association. (2019). American College Health Association National College Health Assessment Spring 2019. Retrieved April 15, 2021, from www.acha.org/documents/ncha/NCHA-II_SPRING _2019_US_REFERENCE_GROUP_DATA_REPORT.pdf

Auchincloss, L. C., Laursen, S. L., Branchaw, J. L., Eagan, K., Graham, M. Hanauer, D. I., ... \& Rowland, S. (2014). Assessment of course-based undergraduate research experiences: A meeting report. CBE-Life Sciences Education, 13(1), 29-40

Bayram, N., \& Bilgel, N. (2008). The prevalence and socio-demographic correlations of depression, anxiety and stress among a group of university students. Social Psychiatry and Psychiatric Epidemiology, 43(8), 667672.

Beiter, R., Nash, R., McCrady, M., Rhoades, D., Linscomb, M., Clarahan, M., \& Sammut, S. (2015). The prevalence and correlates of depression, anxiety, and stress in a sample of college students. Journal of Affective Disorders, 173, 90-96.

Biel, R., \& Brame, C. J. (2016). Traditional versus online biology courses: Connecting course design and student learning in an online setting. Journal of Microbiology \& Biology Education, 17(3), 417.

Bilimoria, D., \& Stewart, A. J. (2009). "Don't ask, don't tell": The academic climate for lesbian, gay, bisexual, and transgender faculty in science and engineering. NWSA Journal, 21(2), 85-103.

Birks, M., \& Mills, J. (2015). Grounded theory: A practical guide. Los Angles, California: Sage.

Bowden, A., Fox-Rushby, J. A., Nyandieka, L., \& Wanjau, J. (2002). Methods for pre-testing and piloting survey questions: Illustrations from the KENQOL survey of health-related quality of life. Health Policy and Planning. 17(3), 322-330.

Brainard, S. G., \& Carlin, L. (1998). A six-year longitudinal study of undergraduate women in engineering and science. Journal of Engineering Education, 87(4), 369-375.

Brown, R. D., Clarke, B., Gortmaker, V., \& Robinson-Keilig, R. (2004). Assessing the campus climate for gay, lesbian, bisexual, and transgender (GLBT) students using a multiple perspectives approach. Journal of College Student Development, 45(1), 8-26.

Bryant, F. B., Kastrup, H., Udo, M., Hislop, N., Shefner, R., \& Mallow, J. (2013). Science anxiety, science attitudes, and constructivism: A binational study. Journal of Science Education and Technology, 22(4), 432448

Castelli, F. R., \& Sarvary, M. A. (2021). Why students do not turn on their video cameras during online classes and an equitable and inclusive plan to encourage them to do so. Ecology and Evolution, 11(8), 3565-3576.

Cavanaugh, J. K., \& Jacquemin, S. J. (2015). A large sample comparison of grade based student learning outcomes in online vs. face-to-face courses. Online Learning, 19(2), n2.

Cech, E. A., \& Waidzunas, T. J. (2011). Navigating the heteronormativity of engineering: The experiences of lesbian, gay, and bisexual students. Engineering Studies, 3(1), 1-24.

Center for Collegiate Mental Health. (2021). 2020 Annual Report (STA 21 045). University Park, PA: Penn State University.

Chapell, M. S., Blanding, Z. B., Silverstein, M. E., Takahashi, M., Newman, B., Gubi, A., \& McCann, N. (2005). Test anxiety and academic performance in undergraduate and graduate students. Journal of Educational Psychology, 97(2), 268.

Chou, T., Asnaani, A., \& Hofmann, S. G. (2012). Perception of racial discrimination and psychopathology across three US ethnic minority groups. Cultural Diversity and Ethnic Minority Psychology, 18(1), 74.

Choukas-Bradley, S., Nesi, J., Widman, L., \& Higgins, M. K. (2019). Camera-ready: Young women's appearance-related social media consciousness. Psychology of Popular Media Culture, 8(4), 473. 
Clemmons, A., Timbrook, J., Herron, J., \& Crowe, A. (2019). BioSkills guide Core competencies for undergraduate biology. Bethesda, MD: QUBES Educational Resources.

Coduti, W. A., Hayes, J. A., Locke, B. D., \& Youn, S. J. (2016). Mental health and professional help-seeking among college students with disabilities. Rehabilitation Psychology, 61(3), 288.

Conrad, D. L. (2002). Engagement, excitement, anxiety, and fear: Learners' experiences of starting an online course. American Journal of Distance Education, 16(4), 205-226. https://doi.org/10.1207/S15389286AJDE1604_2

Cooper, K. M., Auerbach, A. J. J., Bader, J. D., Beadles-Bohling, A. S., Brashears, J. A., Cline, E., ... \& Fuselier, L. (2020a). Fourteen recommendations to create a more inclusive environment for LGBTQ+ individuals in academic biology. CBE-Life Sciences Education, 19(3), es6.

Cooper, K. M., \& Brownell, S. E. (2016). Coming out in class: Challenges and benefits of active learning in a biology classroom for LGBTQIA students. CBE-Life Sciences Education, 15(3), ar37. https://doi.org/10.1187/ cbe.16-01-0074

Cooper, K. M., \& Brownell, S. E. (2018). Developing course-based research experiences in discipline-based education research: Lessons learned and recommendations. Journal of Microbiology \& Biology Education, 19(2).

Cooper, K. M., \& Brownell, S. E. (2020). Student anxiety and fear of negative evaluation in active learning science classrooms. In Walter, E., \& Mintzes, J. J. (Eds.), Active learning in college science, the case for evidence-based practice. Ch 56, New York, NY: Springer Nature.

Cooper, K. M., Brownell, S. E., \& Gormally, C. C. (2019). Coming out to the class: Identifying factors that influence college biology instructor decisions about whether to reveal their LGBQ identity in class. Journal of Women and Minorities in Science and Engineering, 25, 261-282.

Cooper, K. M., Downing, V. R., \& Brownell, S. E. (2018a). The influence of active learning practices on student anxiety in large-enrollment college science classrooms. International Journal of STEM Education, 5(1), 23.

Cooper, K. M., Gin, L. E., Barnes, M. E., \& Brownell, S. E. (2020b). An exploratory study of students with depression in undergraduate research experiences. CBE-Life Sciences Education, 19(2), ar19.

Cooper, K. M., Gin, L. E., \& Brownell, S. E. (2020c). Depression as a concealable stigmatized identity: What influences whether students conceal or reveal their depression in undergraduate research experiences? International Journal of STEM Education, 7, 1-18.

Cooper, K. M., Haney, B., Krieg, A., \& Brownell, S. E. (2017a). What's in a name? The importance of students perceiving that an instructor knows their names in a high-enrollment biology classroom. CBE-Life Sciences Education, 16(1), ar8. https://doi.org/10.1187/cbe.16-08-0265

Cooper, K. M., Krieg, A., \& Brownell, S. E. (2018b). Who perceives they are smarter? Exploring the influence of student characteristics on student academic self-concept in physiology. Advances in Physiology Education, $42(2), 200-208$

Cooper, K. M., Schinske, J. N., \& Tanner, K. D. (2021). Reconsidering the share of a think-pair-share: Emerging limitations, alternatives, and opportunities for research. CBE-Life Sciences Education, 20(1), fe1.

Cooper, K. M., Soneral, P. A., \& Brownell, S. E. (2017b). Define your goals before you design a CURE: A call to use backward design in planning course-based undergraduate research experiences. Journal of Microbiology \& Biology Education, 18(2).

Cotner, S., Thompson, S., \& Wright, R. (2017). Do biology majors really differ from non-STEM majors? CBE-Life Sciences Education, 16(3), ar48.

Culler, R. E., \& Holahan, C. J. (1980). Test anxiety and academic performance: The effects of study-related behaviors. Journal of Educational Psychology, 72(1), 16

Davis, C., Shuster, B., Dionne, M., \& Claridge, G. (2001). Do you see what see? Facial attractiveness and weight preoccupation in college women. Journal of Social and Clinical Psychology, 20(2), 147-160.

Deeks, J. (1998). When can odds ratios mislead? British Medical Journal, 317(7166), 1155. https://doi.org/10.1136/bmj.317.7166.1155a

Deshpande, S. W., \& Kawane, S. D. (1982). Anxiety and serial verbal learning: A test of the Yerkes-Dodson law. Asian Journal of Psychology \& Education. 9(3), 18-23.

DeVaney, T. A. (2010). Anxiety and attitude of graduate students in on-campus vs. Online statistics courses. Journal of Statistics Education, 18(1) $1-16$.
Downing, V. R., Cooper, K. M., Cala, J. M., Gin, L. E., \& Brownell, S. E. (2020) Fear of negative evaluation and student anxiety in community college active-learning science courses. CBE-Life Sciences Education, 19(2), ar20

Eckberg, D. A. (2015). Race and research methods anxiety in an undergraduate sample: The potential effects of self-perception. Journal of Classroom Interaction, 50(2), 145-155.

Eddy, S. L., Brownell, S. E., Thummaphan, P., Lan, M.-C., \& Wenderoth, M. P. (2015). Caution, student experience may vary: Social identities impact a student's experience in peer discussions. CBE-Life Sciences Education, 14(4), ar45. https://doi.org/10.1187/cbe.15-05-0108

Eisenberg, D., Gollust, S. E., Golberstein, E., \& Hefner, J. L. (2007). Prevalence and correlates of depression, anxiety, and suicidality among university students. American Journal of Orthopsychiatry, 77(4), 534-542.

England, B. J., Brigati, J. R., \& Schussler, E. E. (2017). Student anxiety in introductory biology classrooms: Perceptions about active learning and persistence in the major. PLOS ONE, 12(8), e0182506.

England, B. J., Brigati, J. R., Schussler, E. E., \& Chen, M. M. (2019). Student anxiety and perception of difficulty impact performance and persistence in introductory biology courses. CBE-Life Sciences Education, 18(2), ar21.

Fletcher, L. A., \& Carter, V. C. (2010). The important role of community colleges in undergraduate biology education. CBE-Life Sciences Education, 9(4), 382-383

Freeman, S., Eddy, S. L., McDonough, M., Smith, M. K., Okoroafor, N., Jordt H., \& Wenderoth, M. P. (2014). Active learning increases student performance in science, engineering, and mathematics. Proceedings of the National Academy of Sciences USA, 111(23), 8410-8415.

Gaudier-Diaz, M. M., Sinisterra, M., \& Muscatell, K. A. (2019). Motivation, belongingness, and anxiety in neuroscience undergraduates: Emphasizing first-generation college students. Journal of Undergraduate Neuroscience Education, 17(2), A145.

Gibson, S. G., \& Thomas, C. D. (1991). Self-rated competence, current weight, and body-image among college women. Psychological Reports, 69(1), $336-338$.

Gin, L. E., Guerrero, F. A., Brownell, S. E., \& Cooper, K. M. (2021a). COVID-19 and undergraduates with disabilities: Challenges resulting from the rapid transition to online course delivery for students with disabilities in undergraduate STEM at large-enrollment institutions. CBE-Life Sciences Education, 20(3), ar36

Gin, L. E., Scott, R. A., Pfeiffer, L. D., Zheng, Y., Cooper, K. M., \& Brownell, S. E. (2021b). It's in the syllabus... Or is it? How biology syllabi can serve as communication tools for creating inclusive classrooms at a large-enrollment research institution. Advances in Physiology Education, 45(2), 224-240.

Gin, L. E., Wiesenthal, N. J., Ferreira, I., \& Cooper, K. M. (2021c). PhDepression: Examining how graduate research and teaching affect depression in life sciences PhD students. CBE-Life Sciences Education, 20(3) ar41.

Glesne, C., \& Peshkin, A. (1992). Becoming qualitative researchers: An introduction. White Plains, NY: Longman.

Gorbunovs, A., Kapenieks, A., \& Cakula, S. (2016). Self-discipline as a key indicator to improve learning outcomes in e-learning environment. Procedia-Social and Behavioral Sciences, 231, 256-262.

Grant, J. E., Odlaug, B. L., Derbyshire, K., Schreiber, L. R., Lust, K., \& Christenson, G. (2014). Mental health and clinical correlates in lesbian, gay, bisexual, and queer young adults. Journal of American College Health, 62(1), 75-78.

Hancock, D. R. (2002). Influencing graduate students' classroom achievement, homework habits and motivation to learn with verbal praise Educational Research, 44(1), 83-95.

Harris, H. S., \& Martin, E. W. (2012). Student motivations for choosing online classes. International Journal for the Scholarship of Teaching and Learning, 6(2), n2.

Hashmat, S., Hashmat, M., Amanullah, F., \& Aziz, S. (2008). Factors causing exam anxiety in medical students. Journal-Pakistan Medical Association. $58(4), 167$

Here's our list of colleges' reopening models. (2020, October). Chronicle of Higher Education. Retrieved April 15, 2021, from www.chronicle.com/ article/heres-a-list-of-colleges-plans-for-reopening-in-the-fall 
Hilliard, J., Kear, K., Donelan, H., \& Heaney, C. (2020). Students' experiences of anxiety in an assessed, online, collaborative project. Computers $\&$ Education, 143, 103675.

Hood, S., Barrickman, N., Djerdjian, N., Farr, M., Magner, S., Roychowdhury, H., ... \& Ross, K. (2021). "I like and prefer to work alone": Social anxiety, academic self-efficacy, and students' perceptions of active learning CBE-Life Sciences Education, 20(1), ar12.

Hoy, C., Gregg, N., Wisenbaker, J., Manglitz, E., King, M., \& Moreland, C. (1997). Depression and anxiety in two groups of adults with learning disabilities. Learning Disability Quarterly, 20(4), 280-291.

Hsu, J. L., \& Goldsmith, G. R. (2021). Instructor strategies to alleviate stress and anxiety among college and University STEM Students. CBE-Life Sciences Education, 20(1), es1.

Idemudia, E. C., \& Negash, S. (2012). An empirical investigation of factors that influence-anxiety and evaluation in the virtual learning environment. In Proceedings of the Southern Association for Information Systems conference (Atlanta, GA), 116-123. https://doi.org/10.3390/ijerph16122193

Intemann, K. (2009). Why diversity matters: Understanding and applying the diversity component of the National Science Foundation's broader impacts criterion. Social Epistemology, 23(3-4), 249-266.

Judd, L. L., Paulus, M. J., Schettler, P. J., Akiskal, H. S., Endicott, J., Leon, A. C., ... \& Keller, M. B. (2000). Does incomplete recovery from first lifetime major depressive episode herald a chronic course of illness? American Journal of Psychiatry, 157(9), 1501-1504

Kauffman, H. (2015). A review of predictive factors of student success in and satisfaction with online learning. Research in Learning Technology, 23, 1-13. https://journal.alt.ac.uk/index.php/rtt/article/view/1648/pdf_13

Kecojevic, A., Basch, C. H., Sullivan, M., \& Davi, N. K. (2020). The impact of the COVID-19 epidemic on mental health of undergraduate students in New Jersey, cross-sectional study. PLOS ONE, 15(9), e0239696.

Kibbey, M. M., Fedorenko, E. J., \& Farris, S. G. (2020). Anxiety, depression, and health anxiety in undergraduate students living in initial US outbreak "hotspot" during COVID-19 pandemic. Cognitive Behaviour Therapy, 50(3), 409-421.

Lee, J., Jeong, H. J., \& Kim, S. (2021). Stress, anxiety, and depression among undergraduate students during the COVID-19 pandemic and their use of mental health services. Innovative Higher Education, 46, 1-20. https:// link.springer.com/content/pdf/10.1007/s10755-021-09552-y.pdf

Lee, R. M., \& Robbins, S. B. (2000). Understanding social connectedness in college women and men. Journal of Counseling \& Development, 78(4), 484-491.

Leners, D. W., \& Sitzman, K. (2006). Graduate student perceptions: Feeling the passion of caring online. Nursing Education Perspectives, 27(6), 315319.

Levine, R. E., Breitkopf, C. R., Sierles, F. S., \& Camp, G. (2003). Complications associated with surveying medical student depression. Academic Psychiatry, 27(1), 12-18.

Linley, J., Renn, K., \& Woodford, M. (2018). Examining the Ecological Systems of LGBTQ STEM Majors. Journal of Women and Minorities in Science and Engineering, 24(1), 1-16.

Mahmoud, J. S. R., "Topsy," Staten, R., Hall, L. A., \& Lennie, T. A. (2012). The relationship among young adult college students' depression, anxiety, stress, demographics, life satisfaction, and coping styles. Issues in Mental Health Nursing, 33(3), 149-156.

Mallow, J. V. (2006). Science anxiety: Research and action. Handbook of College Science Teaching (pp. 3-14).

Mayo Clinic. (2021). Anxiety disorders-Symptoms and causes. Retrieved April 15, 2021, from www.mayoclinic.org/diseases-conditions/anxiety/ symptoms-causes/syc-20350961

McCarthy, M. (2019). List of accredited online colleges \& universities. OnlineU. Retrieved April 15, 2021, from www.onlineu.com/online-schools

McKeachie, W. J. (1951). Anxiety in the college classroom. Journal of Educational Research, 45(2), 153-160.

McKeachie, W. J., Lin, Y. G., Milholland, J., \& Isaacson, R. (1966). Student affiliation motives, teacher warmth, and academic achievement. Journal of Personality and Social Psychology, 4(4), 457.

Mead, C., Supriya, K., Zheng, Y., Anbar, A. D., Collins, J. P., LePore, P., \& Brownell, S. E. (2020). Online biology degree program broadens access for women, first-generation to college, and low-income students, but grade disparities remain. PLOS ONE, 15(12), e0243916.

Michaluk, L., Stoiko, R., Stewart, G., \& Stewart, J. (2018). Beliefs and attitudes about science and mathematics in pre-service elementary teachers, STEM, and non-STEM majors in undergraduate physics courses. Journal of Science Education and Technology, 27(2), 99-113

Misra, R., \& McKean, M. (2000). College students' academic stress and its relation to their anxiety, time management, and leisure satisfaction. American Journal of Health Studies, 16(1), 41.

Mohammed, T. F., Gin, L. E., Wiesenthal, N. J., \& Cooper, K. M. (unpublished data). The experiences of undergraduates with depression in online science learning environments. CBE-Life Sciences Education.

Morse, J. M., Barrett, M., Mayan, M., Olson, K., \& Spiers, J. (2002). Verification strategies for establishing reliability and validity in qualitative research International Journal of Qualitative Methods, 1(2), 13-22. https://doi org/10.1177/160940690200100202

Nadile, E. M., Alfonso, E., Barreiros, B. M., Bevan-Thomas, W. D., Brownell, S. E., Chin, M. R., ... \& Gomez-Rosado, J. O. (2021). Call on me! Undergraduates' perceptions of voluntarily asking and answering questions in front of large-enrollment science classes. PLOS ONE, 16(1) e0243731.

National Alliance on Mental Illness. (2021). Home page. Retrieved April 15 2021, from www.nami.org/Home

National Council on Disability. (2017). Mental health on college campuses: Investments, accommodations needed to address student needs. Retrieved April 15, 2021, from https://ncd.gov/sites/default/files/NCD _Mental_Health_Report_508_0.pdf

National Institute of Mental Health. (2021). Home page. Retrieved April 15, 2021, from www.nimh.nih.gov

Newcomer, S. N. (2018). Investigating the power of authentically caring student-teacher relationships for Latinx students. Journal of Latinos and Education, 17(2), 179-193.

Ni, M. Y., Kim, Y., McDowell, I., Wong, S., Qiu, H., Wong, I. O., ... \& Leung, G. M. (2020). Mental health during and after protests, riots and revolutions: A systematic review. Australian \& New Zealand Journal of Psychiatry, 54(3), $232-243$.

Orr, T. (2019). Women with depression in online learning: A descriptive phenomenological analysis. https://dt.athabascau.ca/jspui/bitstream/ 10791/292/7/ORR\%2OFINAL\%202019\%20\%281\%29.pdf

Oswalt, S. B., \& Wyatt, T. J. (2011). Sexual orientation and differences in mental health, stress, and academic performance in a national sample of US college students. Journal of Homosexuality, 58(9), 12551280.

Patridge, E. V., Barthelemy, R. S., \& Rankin, S. R. (2014). Factors impacting the academic climate for LGBQ STEM faculty. Journal of Women and Minorities in Science and Engineering, 20(1), 75-98. https://doi .org/10.1615/JWomenMinorScienEng.2014007429

Peterson, C. L., \& Bond, N. (2004). Online compared to face-to-face teacher preparation for learning standards-based planning skills. Journal of Research on Technology in Education, 36(4), 345-360

Protopsaltis, S., \& Baum, S. (2019). Does online education live up to its promise? A look at the evidence and implications for federal policy Bloomington, Indiana: Center for Educational Policy Evaluation.

Rasor, L. T., \& Rasor, R. A. (1998). Test anxiety and study behavior of community college students in relation to ethnicity, gender, and age. https:// files.eric.ed.gov/fulltext/ED415942.pdf

Rawson, H. E., Bloomer, K., \& Kendall, A. (1994). Stress, anxiety, depression, and physical illness in college students. Journal of Genetic Psychology, 155(3), 321-330

Saadé, R. G., Kira, D., Mak, T., \& Nebebe, F. (2017). Anxiety \& performance in online learning. In InSITE 2017: Informing Science + IT Education Conferences: Vietnam (pp. 147-157).

Saldaña, J. (2015). The coding manual for qualitative researchers. Los Angeles, CA: Sage.

Savery, J. R. (2005). BE VOCAL: Characteristics of successful online instructors. Journal of Interactive Online Learning, 4(2), 141-152.

Seymour, E., \& Hewitt, N. M. (1997). Talking about leaving: Why undergraduates leave the sciences. Boulder, CO: Westview Press. 
Sher, A. (2009). Assessing the relationship of student-instructor and student-student interaction to student learning and satisfaction in web-based online learning environment. Journal of Interactive Online Learning, 8(2).

Simon, M. (2000). Managing time: Developing effective online organization. In White, K. W., \& Weight, B. H. (Eds.), The Online Teaching Guide: An Handbook of Attitudes, Strategies, and Techniques for the Virtual Classroom (pp. 73-82). Needham Heights, MA: Allyn \& Bacon.

Sitzman, K. L. (2016). What student cues prompt online instructors to offer caring interventions? Nursing Education Perspectives, 37(2), 61-71.

Soria, K. M., \& Horgos, B. (2021). Factors associated with college students mental health during the COVID-19 pandemic. Journal of College Student Development, 62(2), 236-242.

Spielberger, C. D. (2013). Anxiety: Current trends in theory and research. Tallahassee, FL: Elsevier.

Spitzer, R. L., Kroenke, K., Williams, J. B., \& Löwe, B. (2006). A brief measure for assessing generalized anxiety disorder: The GAD-7. Archives of Internal Medicine, 166(10), 1092-1097.

Stearns, S. A. (2001). The student-instructor relationship's effect on academic integrity. Ethics \& Behavior, 11(3), 275-285.

Stemler, S. E. (2004). A comparison of consensus, consistency, and measurement approaches to estimating interrater reliability. Practical Assessment, Research, and Evaluation, 9(1), 4.

Stiller, K. D., \& Köster, A. (2016). Learner attrition in an advanced vocational online training: The role of computer attitude, computer anxiety, and online learning experience. European Journal of Open, Distance and E-Learning, 19(2), 1-14. https://doi.org/10.1515/eurodl $-2016-0004$

Stowell, J. R., \& Bennett, D. (2010). Effects of online testing on student exam performance and test anxiety. Journal of Educational Computing Research, 42(2), 161-171.

Substance Abuse and Mental Health Services Administration. (2021). SAMHSA's national helpline. Retrieved April 15, 2021, from www.samhsa.gov/ find-help/national-helpline

Supriya, K., Mead, C., Anbar, A. D., Caulkins, J. L., Collins, J. P., Cooper, K. M., ... \& Scott, R. A. (2021). COVID-19 and the abrupt shift to remote learning: Impact on grades and perceived learning for undergraduate biology students. BioRxiv. https://doi.org/10.1101/2021.03.29.437480

Syed, M., \& Nelson, S. C. (2015). Guidelines for establishing reliability when coding narrative data. Emerging Adulthood, 3(6), 375-387.

Teigen, K. H. (1994). Yerkes-Dodson: A law for all seasons. Theory \& Psychology, 4(4), 525-547.
Telzer, E. H., \& Fuligni, A. J. (2009). A longitudinal daily diary study of family assistance and academic achievement among adolescents from Mexican, Chinese, and European backgrounds. Journal of Youth and Adolescence, 38(4), 560-571.

Theobald, E. J., Eddy, S. L., Grunspan, D. Z., Wiggins, B. L., \& Crowe, A. J. (2017). Student perception of group dynamics predicts individual performance: Comfort and equity matter. PLOS ONE, 12(7), e0181336.

Tracking the coronavirus at U.S. colleges and universities. (2020, December 11). New York Times. Retrieved April 15, 2021, from www.nytimes.com/ interactive/2020/us/covid-college-cases-tracker.html

Trenor, J. M., Miller, M. K., \& Gipson, K. G. (2011). Utilization of a think-aloud protocol to cognitively validate a survey instrument identifying social capital resources of engineering undergraduates. Vancouver, British Columbia: American Society for Engineering Education.

Turner, A. N., Challa, A. K., \& Coope, K. M. (2021). Student perceptions of authoring a publication stemming from a course-based undergraduate research experience (CURE). CBE-Life Sciences Education, 20(3), ar46.

Udo, M. K., Ramsey, G. P., \& Mallow, J. V. (2004). Science anxiety and gender in students taking general education science courses. Journal of Science Education and Technology, 13(4), 435-446.

Venegas, K. M. (2007). The Internet and college access: Challenges for low-income students (Vol. 3, pp. 141-154). San Francisco, USA: American Academic.

Vitasari, P., Wahab, M. N. A., Othman, A., Herawan, T., \& Sinnadurai, S. K. (2010). The relationship between study anxiety and academic performance among engineering students. Procedia-Social and Behavioral Sciences, 8, 490-497.

Waschull, S. B. (2005). Predicting success in online psychology courses: Self-discipline and motivation. Teaching of Psychology, 32(3), 190-192.

Wasserstein, R. L., Schirm, A. L., \& Lazar, N. A. (2019). Moving to a world beyond " $p<0.05$." Taylor \& Francis.

Watson, D., \& Friend, R. (1969). Measurement of social-evaluative anxiety. Journal of Consulting and Clinical Psychology, 33(4), 448.

Weeks, J. W., Heimberg, R. G., Fresco, D. M., Hart, T. A., Turk, C. L., Schneier F. R., \& Liebowitz, M. R. (2005). Empirical validation and psychometric evaluation of the Brief Fear of Negative Evaluation Scale in patients with social anxiety disorder. Psychological Assessment, 17(2), 179.

Wickens, T. D., \& Keppel, G. (2004). Design and analysis: A researcher's handbook. Upper Saddle River, NJ: Pearson Prentice-Hall.

Wyer, M., Barbercheck, M., Geisman, D., Ozturk, H. O., \& Wayne, M. (2001). Female, science and technology: A reader in feminist science. New York: Routledge. 